\title{
Government Failure and Market Failure: On the Inefficiency of Environmental and Energy Policy
}

Link to publication record in Manchester Research Explorer

\section{Citation for published version (APA):}

Anthoff, D., \& Hahn, R. (2010). Government Failure and Market Failure: On the Inefficiency of Environmental and Energy Policy. (SCI Discussion Paper Series; No. 2).

http://www.sci.manchester.ac.uk/medialibrary/sci_discussionpaper_no2.pdf

\section{Citing this paper}

Please note that where the full-text provided on Manchester Research Explorer is the Author Accepted Manuscript or Proof version this may differ from the final Published version. If citing, it is advised that you check and use the publisher's definitive version.

\section{General rights}

Copyright and moral rights for the publications made accessible in the Research Explorer are retained by the authors and/or other copyright owners and it is a condition of accessing publications that users recognise and abide by the legal requirements associated with these rights.

\section{Takedown policy}

If you believe that this document breaches copyright please refer to the University of Manchester's Takedown Procedures [http://man.ac.uk/04Y6Bo] or contact uml.scholarlycommunications@manchester.ac.uk providing relevant details, so we can investigate your claim.

\section{OPEN ACCESS}




\section{Consumption Institute}

\section{SCI DISCUSSION PAPER}

\section{Government Failure and Market Failure: On the Inefficiency of Environmental and Energy Policy}

By:

\section{Dr David Anthoff}

Economic and Social Research

Institute, Dublin

Dr Robert W. Hahn,

Sustainable Consumption Institute,

The University of Manchester

Georgetown Center for Business and Public Policy

Smith School of Enterprise and the

Environment, University of Oxford
Revised: March 2010

Prepared for the Oxford

Review of Economic

Policy 
The Sustainable Consumption I nstitute ( SCI) was established in 2007 as a world leading, interdisciplinary research institute at The University of Manchester. A key to our success will be to work cooperatively with government, business and the consumer. For more information, visit: http://www.sci.manchester.ac.uk

SCI DI SCUSSI ON PAPERS are intended to stimulate discussion among researchers, practitioners and policy makers on a range of current and emerging sustainability issues.

\section{Published by:}

Sustainable Consumption Institute

The University of Manchester

188 Waterloo Place

Oxford Road

Manchester, UK

M13 9PL

Telephone +44(0) 1612754030

\section{The authors:}

David Anthoff is a post doctoral associate at the Economic and Social Research Institute, Dublin.

Robert Hahn is Tesco Professor of Economics, Sustainable Consumption Institute, University of Manchester, a senior visiting fellow at the Smith School, University of Oxford and a senior fellow at the Georgetown Center for Business and Public Policy. 


\title{
Government Failure and Market Failure: On the I nefficiency of Environmental and Energy Policy
}

\author{
David Anthoff and Robert Hahn*
}

June 2009

Revised: March 2010

Prepared for the Oxford Review of Economic Policy

\footnotetext{
* David Anthoff is a post doctoral associate at the Economic and Social Research Institute, Dublin. Robert Hahn is a senior visiting fellow at the Smith School, University of Oxford and a senior fellow at the Georgetown Center for Business and Public Policy. We would like to thank Jessica Coria, Denny Ellerman, David Frame, Paul Gorecki, Lawrence Goulder, John Graham, Dieter Helm, Cameron Hepburn, Åsa Löfgren, Seán Lyons, David Maddison, Al McGartland, Robert Mendelsohn, I an Parry, Robert Stavins, Thomas Sterner, David Victor, Herman Vollebergh, and Michael Wara for helpful suggestions. Emily Giovanni, J ohn M. Schmitz and Poh Lin Tan provided valuable research assistance. The views expressed in this paper reflect solely those of the authors and do not necessarily reflect those of the institutions with which they are affiliated. (c) 2009 by the authors. All rights reserved.
} 


\begin{abstract}
In this essay, we describe some important themes in energy and environmental policy. There are two main reasons for our interest in these policies. First, such policies will likely be important in the coming decades as issues related to climate change and energy security come to the fore. Second, there are important lessons to be learned from a careful review of the actual performance of energy and environmental policies. We undertake a selective survey of the literature to highlight what is known about the efficiency of particular kinds of policies, laws and regulations in these areas.

There are three key contributions of this paper. The first is to synthesize a large literature on energy and environmental policy in a way that can be easily digested by both non-experts and experts. The second contribution is to suggest that, if history is a guide, then we should not expect many interventions in these policy areas to come close to maximizing net economic benefits. The third is to suggest what might be needed for the development of more efficient energy and environmental policies.
\end{abstract}

Key Words: Environmental and resource economics, energy economics, political economy, benefit-cost analysis, regulation, economic instruments, climate change policy 


\title{
Government Failure and Market Failure: On the I nefficiency of Environmental and Energy Policy
}

\author{
David Anthoff and Robert Hahn
}

\section{Introduction}

In this essay, we characterize some important themes in energy and environmental policy. As economists we are particularly interested in the relative effectiveness and efficiency of various polices: that is, whether a specific policy meets its intended goals, and whether that policy is likely to do more good than harm when important impacts, such as those related to the environment, health, safety, or energy security, are taken into account.

There are two main reasons for our interest in energy and environmental policies. First, we believe such policies will be critically important in the coming decades as issues related to climate change and energy security come to the fore. Second, we believe there are important lessons to be learned from a careful review of the actual performance of energy and environmental policies.

Our focus will be on recent empirical studies of energy and environmental policies. We undertake a selective survey of the literature to highlight what is known about the efficiency of particular kinds of policies, laws and regulatory interventions in the area of the environment and energy. Efficiency is defined in conventional economic terms to represent the impact on consumers and producers (i.e., the sum of consumer and producer surplus).

We will examine cases of both "market failure" and "government failure." A market failure can arise if there are externalities, such as pollution; or if there are inefficiencies associated with market structure, such as a cartel. A government 
failure can arise if the government selects a policy, such as subsidizing energy, which leads to an inefficient outcome. In certain cases, this outcome may actually reduce overall economic efficiency compared with the status quo. Government failures may arise for a number of reasons. For example, politicians or regulators may simply not have an incentive to pursue efficient policies. In addition, regulators may lack adequate information. Both market failures and government failures can contribute to the inefficient use of energy and environmental resources if they are not rectified.

Our empirical analysis does not focus on the impacts of policies on specific groups of consumers or businesses. While we believe such equity concerns are important, an empirical examination of these issues is beyond the scope of this paper. We do, however, address the relationship between equity and efficiency when we examine how to make policies more efficient.

There are three key contributions of this paper. The first is to synthesize a large literature on energy and environmental policy in a way that can be easily digested by both non-experts and experts. To that end, our review of the empirical literature makes liberal use of figures and graphs to present key arguments. The second contribution is to suggest that, if history is any guide, then we should not expect future interventions in these policy areas to maximize net economic benefits. The third is to suggest what might be needed for the development of energy and environmental policies that increase net benefits, or economic efficiency. Throughout the paper, we consider how our general observations apply to climate change policy.

The findings of the paper can be summarized briefly. In many cases, energy and environmental policy increase efficiency in the sense that a particular policy intervention does more economic good than harm. In many cases, however, they do not. Furthermore, 
many energy and environmental policies fail to come close to maximizing net economic benefits. After developing these arguments, we explore how one might actually improve the efficiency of energy and environmental policy.

The plan of the paper is as follows. Section 2 provides a synthesis of the empirical literature on energy and environmental policy. Section 3 reviews some key issues in political economy related to developing and implementing more efficient policy. Finally, section 4 concludes and suggests areas for future research.

\section{An Empirical Review of Energy and Environmental Policy}

In this section, we provide a selective review of energy and environmental policy. The review focuses on the economic efficiency of particular policies. The primary market failure that is addressed relates to pollution, though we also consider other possible externalities associated with traffic congestion and safety. We do not explicitly consider the cause of government failures in this section, though we do illustrate that many government interventions are economically inefficient. In section 3, we suggest some approaches for making policies more efficient and reducing the extent of government failures.

We wish to provide an overview of important themes that emerge from an analysis of energy and environmental policies. To this end, we systematically reviewed articles in the following publications from the year 2000 to July 2009: American Economic Review, Energy Economics, Environmental and Resource Economics, Journal of Environmental Economics and Management, Journal of Economic Perspectives and Resource and Energy Economics. We examined titles and abstracts that appeared to be relevant to environmental and energy policy, and selected those we thought most relevant. In addition, we reviewed other scholarship and government publications in areas that we thought were important, 
including key review articles and citations to those articles. We undoubtedly left out some important work in doing this search. Nonetheless, we hope to have captured many (if not most) of the important economic themes that are presented in the literature. ${ }^{1}$

\section{A. Efficiency of Regulations and Laws}

There is a great deal of work on the relative efficiency of regulations and laws in the United States, and some work on other regions (Guasch and Hahn, 1999). This work suggests that many regulations pass a benefit-cost test, but many do not. In addition, there is significant room for improving economic efficiency of both laws and regulations.

Figure 1 provides an overview of the annual costs and benefits of 93 major regulations as defined by the U.S. Office of Management and Budget (OMB) for federal rules from 1997 through 2007. To be included in OMB's report, a regulation had to generate costs or benefits of at least $\$ 100$ million in any one year, and a substantial portion of its benefits and costs had to be quantified and monetized. All estimates are based on an agency's analysis before the regulation in question was issued (OMB, 2008). While benefitcost analysis applied to major regulations is often subject to great uncertainties, we nevertheless believe that important lessons can be drawn about the efficiency of regulation from reviewing the data.

Following the $\mathrm{OMB}$, we report a range of costs and a range of benefits for each agency or department. The key point to be gleaned from the figure is that, at least by OMB's reckoning, each agency passed regulations whose total benefits are likely to have exceeded their total costs, except one-the Department of Agriculture. This can be seen in the figure by noting that the range

\footnotetext{
${ }^{1}$ When sources specified the year dollars that were used, we note that here. In cases where we could not find the year dollar used in the original study, we cite the dollar amount as in the original.
} 
of benefits is generally above the range of costs for all agencies except one. ${ }^{2}$ The U.S. Environmental Protection Agency looks particularly good using this assessment, primarily because of the expected benefits attributable to particulate matter reduction.

The finding that most agencies examined by OMB are intervening in ways that produce net benefits does not imply that every regulation passed by an agency is likely to result in positive net benefits. It does suggest, however, that government intervention has had some salutary effects based on these numbers, a point noted by several scholars (Sunstein, 2002; Graham, 2008).

The OMB analysis is consistent with a study by Hahn that suggests that the net benefits of federal regulation from 1981 to 1996 are positive (Hahn, 2000). Hahn argues that the government can increase the net benefits of regulation substantially, because less than half the rules he examined would likely pass a benefit-cost test based on quantified benefits and costs. He also notes that just two rules in his sample-the Department of Transportation's automatic restraints in cars and the Environmental Protection Agency's lead phasedown in gasoline-account for more than half of the total net benefits of regulation.

OMB's analysis has many deficiencies, as do other analyses based on similar data. Some of these were highlighted in its report. One is that the study relies on analysis done before a regulation is passed. The picture of gains and losses from a regulation or regulatory program frequently look very different before the fact and after the fact (Winston, 1998; Harrington et al., 2000). A second is that there is a great deal of uncertainty in the underlying

\footnotetext{
${ }^{2}$ If one takes the midpoint of the range of cost and subtracts it from the midpoint of the range of benefits for the Department of Agriculture, the net benefits of regulation for this agency would be negative. Even for this agency, the net benefits could be positive if costs were at the low end of the range and benefits were at the high end of the range.
} 
estimates, and related to that, some aspects of benefits and costs are very difficult to quantify.

There has been some work on environmental and energy laws and programs, and the picture for net benefits is mixed. For example, using EPA estimates, Freeman (2002) suggests that proposed standards for particulate matter would have resulted in significant net benefits, but proposed standards for controlling ground-level ozone would have resulted in net costs. Portney (1990) argues that the Clean Air Act Amendments of 1990 would likely have many programs that result in positive net economic benefits, including the introduction of allowance trading for reducing sulfur dioxide emissions. In some cases, such as the regulations of toxic substances, they argue that the law would likely impose more costs than benefits. Moreover, there is evidence suggesting that the net benefits of the program to control air pollution are higher than those for controlling water pollution. Indeed the net benefits associated with water pollution control may be negative (Freeman III, 2002).

In addition to research that reviews the overall net benefits of laws and regulations, some scholarship examines the detailed patterns emerging from studying specific regulations. Hahn et al. (2000) study the mortality implications of regulatory costs imposed by 24 federal regulations. They investigate whether those regulations are likely to have the unintended effect of increasing mortality risk. This risk could increase, for example, if the resources available for direct expenditures on health were substantially reduced as a result of the increased costs of a particular regulation. The authors find that an unintended increase in total risk is likely to occur for the majority of regulations they examine. At the same time, aggregate mortality risk falls for those regulations, in large part because a few regulations yield large reductions in risk. The 
authors find that, of the 24 rules they examine, more than half (15) would fail a benefit cost-test. Moreover, a substantial number would likely result in increases in mortality as a result of the tradeoff between reduced income and increased mortality. Even if one is skeptical of the association between income and mortality, this work suggests that many U.S. federal regulations in the environmental area not likely to pass a benefit-cost test.

One of the longer time series aimed at addressing the effectiveness of regulations was developed by Morrall to evaluate environmental, health, and safety regulation. Figure 3 plots data on the cost per statistical life saved-a measure of how effective a regulation is at extending the life-span of the affected population (Morrall, 2003). For regulations aimed primarily at extending life, this measure closely tracks conventional economic efficiency measures.

Figure 2 covers 79 final regulations, broken down into three categories: regulations aimed at improving safety ("safety"); regulations aimed primarily at reducing cancer ("toxin control"); and a miscellaneous category labeled "other." Two key trends are evident from the data. First, the toxin control regulations appear to cost more at the margin than do safety regulations for each statistical life saved (Tengs et al., 1995). Second, there is substantial variation within and across both the safety and the toxin control categories (Tengs et al., 1995; Morrall, 2003). The cost per statistical life saved ranges from $\$ 100,000$ to $\$ 100$ billion (in 2002 dollars). For example, the Consumer Product Safety Commission's 1993 rule for childproof lighters only costs $\$ 100,000$ per statistical life saved, while the Environmental Protection Agency's 1991 solid waste disposal rule costs over $\$ 100$ billion per statistical life saved. In addition, the variation in the cost per statistical life saved increases significantly in the 19 years after 1986 compared with the 
19 years before 1986, suggesting that there may now be greater potential gains in reallocating resources across life-saving investments (Hahn and Tetlock, 2008). In particular, there appear to be ample opportunities for refocusing regulations away from those with a high cost per statistical life saved and toward those with a low cost per statistical life saved. The result would be that regulation could either save more lives, or reduce expenditures, or both (Tengs and Graham, 1996). Similar results for the cost per statistical life saved over various regulations have been found in studies looking at Japan (Kishimoto et al., 2003) and Sweden (Ramsberg and Sjöberg, 1997).

Winston (2006) provides a careful and comprehensive analysis of the empirical evidence on the economic impact of government policies to correct market failures in the United States. He finds that government interventions frequently occur when no significant market failure exists. In addition, many policies aimed at addressing market failures could have corrected them at significantly lower cost. In reviewing the welfare costs of market failure, Winston notes several cases where there are substantial inefficiencies. Examples include inefficient pricing and investment in highways, airports, and public transit. ${ }^{3}$ The fact that such infrastructure investments tend to be inefficient may have important implications for climate change policy, where infrastructure plays an important role in both reducing emissions and adapting to the problem.

\section{B. Economic Instruments}

Economists have suggested that regulating environmental pollution with "economic instruments" can lead to significant cost savings compared with so-called "command and control"

\footnotetext{
3 Annual deadweight losses of about $\$ 24$ billion, $\$ 18$ billion and $\$ 9$ billion respectively (see Winston, 2006, p. 74).
} 
approaches. Here, we provide a brief review of the empirical literature, focusing on important applications, such as the marketbased approach for reducing sulfur dioxide in the United States. ${ }^{4}$ We find that market-based approaches for meeting environmental targets have generally resulted in cost savings. We also find that these approaches could be designed to improve economic efficiency in a number of ways, including choosing a target that carefully balances economic benefits and costs, designing an economic approach that more closely links firm behavior to actual economic damages, and having the government spend revenues that may accrue from a particular regulatory approach more efficiently.

Two prime examples of market-based approaches discussed in the literature are taxes and marketable permits. Taxes typically limit pollution by forcing the polluter to pay a unit tax on emissions. If the tax is the same for everyone, then each polluter sets the unit tax equal to the marginal cost of emissions and this theoretically leads to emissions being reduced at minimum cost. The idea behind marketable permits is similar. Each polluter must have permits to cover the amount of emissions she emits. So for example, if a polluter emits 30 pounds of pollution, she might need 30 permits. The overall level of permits is set by the government. They can then be bought or sold freely in the marketplace. In a well-functioning market, emitters have an incentive to emit up to the point where the marginal cost of reducing emissions equals the price of a permit, again leading to a least cost solution.

In theory, if one is interested in maximizing economic benefits, the tax should be set so as to equate the marginal benefits and costs of pollution. Similarly, if one is using a quantity-based instrument, such as a marketable permits, the overall quantity

\footnotetext{
${ }^{4}$ For a comprehensive overview of existing market based policies see Stavins (2003). We do not discuss specific applications of pollution taxes. For a collection of ex-post studies of pollution taxes see Muller and Sterner (2006).
} 
should be set so as to equate the marginal benefits and costs of pollution. ${ }^{5}$

Economists have examined the properties of a number of different marketable permit systems. ${ }^{6}$ The general finding is that they have the potential to both reduce overall control costs and/or improve environmental quality (Baumol and Oates, 1988). In practice, however, they frequently fall short of their potential.

The benchmark used to evaluate a market-based approach is typically a command-and-control regime that often involves technological requirements that the regulator might impose to achieve a similar environmental objective. Not surprisingly, economists find most market-based approaches have the potential to produce cost savings.

Tietenberg provided an early review of studies of potential cost savings from marketable permit systems, which he recently updated (Tietenberg, 2006). Figure 3 summarizes simulation studies that compare command-and-control approaches with marketable permit regimes. The studies suggest that the range of potential cost savings is large. Most of the studies predict cost savings above $40 \%$ by moving to marketable permits from an existing command and control approach, and some predict cost savings above $90 \%$.

A number of authors have provided ex-post estimates-that is, estimates after the event-of the actual impact of introducing marketable permit systems. An early ex-post analysis by Hahn and Hester (1989) on an EPA emission trading system for air pollutants suggested that there were cost savings between $\$ 1$ and 12 billion through 1985, with little change in environmental quality. EPA's

\footnotetext{
5 See Weitzman (1974) for a more sophisticated analysis that considers uncertainty.

${ }^{6}$ We focus on empirical assessments of recent permit markets, primarily because we found more data on large-scale applications of this instrument.
} 
original ex-ante estimate-that is, an estimate done before the event- of cost savings from the lead trading program was $\$ 200$ million between 1985 and 1987 relative to a command-and-control based system that would have achieved similar environmental results (U.S. Environmental Protection Agency, 1985, pp. E-3). Actual cost savings may have been much higher, given that observed banking was higher than the EPA study suggested.

The flagship U.S. $\mathrm{SO}_{2}$ allowance trading regime, which cut nationwide $\mathrm{SO}_{2}$ emissions in the U.S. by 50 percent below 1980 levels by 2000 (Stavins, 1998, p. 70), has been studied extensively. Here, we focus on ex-post studies because they are based on actual data from the performance of the market (see Table 1). ${ }^{7}$ Early studies of the $\mathrm{SO}_{2}$ trading program based on data from the first two years of trading were somewhat ambiguous on estimated costsavings. Carlson et al. (2000) found that costs under the trading system were actually higher in the first two periods than they would have been under prescriptive regulation ${ }^{8}$. Ellerman et al. (2000) estimated $\$ 358$ million per year in cost savings.

Keohane (2006) examined the entire first phase of trading from 1995-1999. His study improves upon previous studies by using data for five years rather than two. He employs an econometric model of abatement choice actually made by utilities to estimate behavior under prescriptive regulation, whereas previous studies used engineering estimates or least-cost algorithms to estimate the counterfactual baseline. Keohane found annual abatement cost savings of $\$ 150-\$ 180$ million, corresponding to cost savings of

\footnotetext{
7 The relationship between ex ante and ex post studies is not always clear. See discussion in Hahn and Tetlock (2008) and Harrington, Morgenstern et al. (2000).

${ }^{8}$ Carlson et al. (2000) offer two explanations for this surprising result twofold. First, their model does not account for short-term adjustment costs. Second, they argue that little trading occurred in the first two years of the program because utilities were not used to managing allowances and because it takes time to establish a functioning market. They observe that in later periods trading volume grew, both between firms as well as within firms across different facilities.
} 
$17 \%-20 \%$ relative to a regime with performance standards. In a different analysis, he estimates that a technology standard requiring scrubbers would have been 3.5 times more expensive than the market outcome.

The European Trading System (ETS) for $\mathrm{CO}_{2}$ emissions is another major application of a pollution permit trading market, at least in aspiration if not in actual performance during the early years. It started in 2005 with a three year trial period that was not linked to later trading periods, and since 2008 the regular operation of this market has started. The trial period was characterized by high volatility of permit prices and a complete collapse of the permit price in the year 2007, leading to speculation by some observers that too many permits might have been allocated to firms so that no emission reduction at all was achieved.

A series of ex-post studies of the first period of the EU ETS found that there were emission reductions, but they were not large (see Table 1). For example Ellerman and Buchner (2008) estimated that there were emission reductions in the range of 50-100 Mton $\mathrm{CO}_{2}$ per year. Other studies confirm that the EU ETS had a positive impact on reducing emissions; however, the magnitude of reductions is very small compared to worldwide $\mathrm{CO}_{2}$ emissions due to human activity of about $28 \mathrm{Gton} \mathrm{CO}_{2}$ in 2006 .

The reductions also fall short of the ambitious targets often discussed by politicians (Helm, 2009). Compared to the U.S. $\mathrm{SO}_{2}$ trading program that had a significant impact on environmental quality, the EU ETS so far has delivered very modest changes in environmental quality. At the same time it is worth stressing that this is not a failure of the instrument itself, but rather a result of the very modest goals that policy makers achieved during the first period of the EU ETS. It is not possible to compare EU ETS cost savings with other market-based regimes because we have not 
been able to find published estimates of these savings. This would be a useful area for future research as the ETS program evolves.

Based on the gap between the theory and practice of implementing marketable permit regimes, there are several ways in which their cost-effectiveness and efficiency could be enhanced. Within the current approach to regulation, we consider two possible efficiency enhancements. The first is to expand the scope of trading and the second is to eliminate constraints that do not help achieve the environmental target. ${ }^{9}$

Both the $\mathrm{SO}_{2}$ allowance trading regime and the EU ETS placed restrictions on their scope that led to unnecessary increases in the cost of achieving the environmental objective. The $\mathrm{SO}_{2}$ allowance trading regime targeted electric utilities, and did not include industrial sources of sulfur dioxide, which were regulated separately. The EU-ETS covered a little less than half of total European $\mathrm{CO}_{2}$ emissions, including power plants and five major industrial sources. Some important sectors, such as transport and housing, were not included. No attempt was made to reduce overall costs of the policy by equalizing marginal abatement costs across sectors that were covered by the EU ETS and sectors that were not (Tol, 2009)

In addition, both the $\mathrm{SO}_{2}$ market and the EU ETS market were implemented in the presence of other regulations that made the systems unnecessarily costly. In the case of the $\mathrm{SO}_{2}$ allowance trading market, regulations that required new power plants to be cleaner than existing power plants were maintained. As discussed below, there are political forces that frequently work to discriminate against new sources in this way. However, there is little, if any, justification for such additional regulation when an economic

\footnotetext{
${ }^{9}$ See the discussion below in Section 3 for why politics may make it difficult to remove such constraints.
} 
instrument already limits the overall amount of pollution to a specified level.

In the EU ETS there were also several regulations that had no effect on reaching the environmental goal, though they may have had some salutary effects on reducing energy consumption of fossil fuels. These included the European Commission's goal of a 20 percent share of renewable energy sources as well as the target of an improvement in energy efficiency of 20 percent. The setting of these multiple targets does not appear to be justified on economic grounds (Helm, 2009). One example is the requirement placed on utilities in Germany to buy all electricity generated by renewable energy sources at prices set by the government. The governmentset prices are substantially higher than the market price for electricity, and differ for different kinds of renewable energy. For example solar generated power fetches a higher price than wind power (Frondel et al., 2008). The subsidies for different kinds of power do nothing to reduce directly the quantity of $\mathrm{CO}_{2}$ emissions because this is limited by the EU ETS. Thus, one must weigh any remaining social benefits of subsidizing these sources of power against the costs. ${ }^{10}$

There are two other key areas for design improvements that researchers have highlighted, but have yet to be translated into environmental policy design effectively. One is to tie the design of an economic instrument more closely to economic damages. The second is to use revenues that may result from implementing an economic instrument in ways that yields even greater efficienciessuch as by cutting taxes that are particularly inefficient or investing in promising research and development.

10 Note that in principle there might be other market failures, such as to economies of scale or learning by doing, that could justify some transitory support for new technologies. 
The idea of balancing overall costs and benefits in designing economic instruments has been around for some time. In general, however, considerations of quantitative marginal damages have played little role in the actual design of permit markets. Montgomery (1972) points out the need to consider multiple markets if an emissions source has different effects on different areas.

Only recently has there been empirical work assessing the potential gain from including the marginal damages associated with different emission sources in a market-based system. Muller and Mendelsohn define damages of $\mathrm{SO}_{2}$ emissions to include "premature mortalities, cases of illness, reduced timber and crops yields, enhanced depreciation of man-made materials, reduced visibility, and recreation usage." (Muller and Mendelsohn, forthcoming, p. 16). They consider the possibility of a trading system that reflects spatially-variant damages from different sources. Under this approach, damage-weighted trading ratios would be introduced that require sources that cause higher damages to hold more permits per unit of emissions than sources that cause lower damages. ${ }^{11}$ The authors find that if the level of $\mathrm{SO}_{2}$ emissions were kept constant, but permit requirements per source were adjusted by their marginal damages, additional annual net benefits of $\$ 300$ to $\$ 900$ million (in 2000 dollars) could be realized (Muller and Mendelsohn, forthcoming, p. 25). These cost savings are similar in magnitude to the cost savings estimated from introducing the marketable permit system instead of a command-and-control regulation (see Table 1). The authors also estimated that if the total cap were adjusted from 10.2 million tons of $\mathrm{SO}_{2}$ to roughly 1 million tons, so that marginal abatement would equal marginal damages at each source, additional annual net benefits of $\$ 7$ to 9 billion USD over the current

\footnotetext{
${ }^{11}$ Spatially differentiated emission taxes could yield similar results.
} 
system could be realized (Muller and Mendelsohn, forthcoming, p. 25). This example clearly illustrates that there are efficiency gains that could be achieved by selecting a more efficient target as well as achieving a particular target in a least cost fashion.

Climate change offers an important example of how making better use of some of the design principles discussed above can lead to substantial increases in efficiency. From an efficiency perspective, the world as a whole is doing too little to reduce net $\mathrm{CO}_{2}$ emissions. Most of the world's countries are doing little or nothing to limit $\mathrm{CO}_{2}$ emissions, yet almost all economic studies find significant marginal damages from emitting $\mathrm{CO}_{2}$ into the atmosphere. Nordhaus' latest estimate finds a social cost of carbon of $\$ 27 /$ tC (Nordhaus, 2008, p. 15) and a meta study of social cost of carbon estimates by Tol (2008) finds a social cost of carbon of $\$ 20 /$ tC. $^{12} 13$

Obstacles to implementing an efficient global policy on climate change are more significant than in a national context because of problems with free-riding and an uneven distribution of benefits and costs across countries. ${ }^{14}$ The one attempt at a global treaty on climate change with quantitative emission limits fared poorly in economic and environmental terms. Kyoto will most likely fail to achieve any significant emission reductions, largely because it did not include major $\mathrm{CO}_{2}$ emitting countries, such as the US, India and China. Countries that will meet their targets in many cases will do so because they were able to buy "hot air" allowances from the

\footnotetext{
12 Tol uses fairly conservative assumptions about discounting. He also uses no distributional weights that would give more weight, say, to impacts in regions with low income. If these assumptions are relaxed, uncertainty over the appropriate social cost of carbon increases, as does a reasonable upper bound for this estimate.

${ }^{13}$ We ignore the contentious debate about the results of the Stern Review on climate change here. Even the conservative estimates of economic damages cited above would warrant more stringent action than is currently being taken.

${ }^{14} \mathrm{~A}$ large literature on the likelihood of a global agreement on climate change has suggested that an efficient global warming policy is highly unlikely (see, e.g., Barrett, 1994; Schelling, 1998).
} 
former Soviet and Eastern European countries. ${ }^{15}$ An economic assessment of the original Kyoto proposal by Nordhaus and Boyer (2000) suggested why the U.S. may not have elected to ratify the protocol. It would have borne the majority of mitigation costs, but not enjoy a comparable level of benefits, even when the interests of future U.S. citizens were taken into account.

Another important area where there may be significant efficiency gains is through judicious spending of revenues that may be generated by economic instruments. A marketable permit program can raise revenue by auctioning off some or all of the allowances. A tax program raises revenues directly. Several scholars have noted the efficiency properties of raising revenues if the money is spent wisely-say, to reduce other distorting taxes. For example, Parry et al. (1999) examine the costs of achieving different carbon emission reduction goals via a carbon tax (or auctioned marketable permits) where revenues are used to cut distorting labor tax rates. They compare this approach with achieving the same emission reductions via a carbon quota or grandfathered carbon permits with no adjustment to distorting labor taxes. They estimate that for a $5 \%$ reduction in emissions, a quota with no tax adjustment is almost 6 times as costly as a regulation that cuts distorting taxes, and for a $15 \%$ reduction costs are 2.6 times higher for the carbon quotas (or grandfathered permits).

Unfortunately, the revenues that accrue from taxation and marketable permits are not always spent with the objective of increasing overall economic welfare. ${ }^{16}$ Hahn (2009) reviews the evidence related to greenhouse gas auctions and taxes, and notes that at least some of the revenues are not likely to have been spent

\footnotetext{
${ }^{15}$ Some countries received more allowances allocated than they needed to cover their total emissions. When they sell these excess allowances, they will not have to reduce emissions because the allowances were not needed in the first place. Such allowances are often referred to as "hot air" allowances.

${ }^{16}$ See discussion below.
} 
wisely from a narrow efficiency perspective. Furthermore, given political pressures, he suggests that it is not reasonable to presume that revenues from the application of new market-based approaches for environmental protection will be driven by concerns with maximizing economic efficiency. ${ }^{17}$ This phenomenon of using revenues inefficiently is not limited to revenues from environmental taxation or regulation. Becker and Mulligan (2003) find that when the government obtains new general revenue, it tends to finance more spending rather than decrease taxes.

\section{Subsidies and Removal of Subsidies}

In this section, we focus primarily on subsidies that directly affect energy use and pollution. We do not, for example, examine subsidies for research and development, some of which had positive economic effects and others of which had adverse effects. ${ }^{18}$

Surprisingly little is known about the overall effect of removing subsidies on energy consumption and the environment. There are a number of studies of individual subsidies and their impacts, but few studies that aggregate the impacts of different subsidies. We think this could be an important area for future research because subsidies are widespread, and in some cases, they are known to have adverse effects on both the environment and the economy (Victor, 2009). We first summarize the literature that addresses overall levels of subsidies, and energy subsidies in particular. Then, we provide a brief review of some studies that address the impact of removing subsidies on environmental impacts.

\footnotetext{
${ }^{17}$ Given current budgetary pressures, at least some of the revenues from a tax or an auction would likely be allocated to repaying government debt.

${ }^{18}$ For an overview of some of the issues related to subsidizing energy research and development, see Jaffe et al. (2005) and Cohen and Noll (1991).
} 
A study by van Beers and de Moor (2001) reveals that subsidies are substantial in both the OECD and non-OECD countries for the years 1994-1998. ${ }^{19}$ The key results are presented in Figure 4. Subsidies total over $\$ 1$ trillion for those years, two-thirds of which are in OECD countries. About 40 percent of subsidies go to agriculture (mostly in OECD countries), and 20 percent go to energy.

The economic, energy and environmental impacts of the various subsidies are not well understood and will depend on the design of the subsidy. For example, subsidies that encourage production and consumption can be expected to have harmful effects. In contrast, "lump-sum" subsidies that are unrelated to specific output or consumption levels can be expected to have much smaller impacts on energy use and the environment.

While not quantified in the van Beers and de Moor study, it appears that a large portion of the subsidies are for areas that could result in significant adverse environmental impacts. We conjecture that these subsidies are likely to do more harm than good in environmental terms because they will often encourage the use of energy or energy-intensive products.

Some recent work by the International Energy Agency provides insights into the allocation of energy subsidies across nonOECD countries. This work defines an intervention as a subsidy if it leads to the energy prices that would be below those achieved by a free market. So, for example, energy related consumption subsidies would fall under this category.

\footnotetext{
19 The definition of a subsidy used by van Beers and de Moor is "Subsidies comprise all measures that keep prices for consumers below market level or keep prices for producers above market level or that reduce costs for consumers and producers by giving direct or indirect support" (van Beers and de Moor, 2000, p. 4).
} 
In 2007, for the 20 non-OECD countries covered in the International Energy Agency analysis, total subsidies for energy were about $\$ 310$ billion. Oil is most heavily subsidized in the nonOECD countries, accounting for about half of all energy subsidies (International Energy Agency, 2008, p. 62). The three non-OECD countries with the highest level of energy subsidies were Iran, Russia and China. Together, they account for about 47 percent of total energy subsidies in non-OECD countries. ${ }^{20}$

To our knowledge, one of the few studies that attempts to synthesize the impacts of energy subsidies on the environment was done by David Pearce (2003), who was a pioneer in this area. ${ }^{21}$ Table 2 reproduces some early work by Pearce and adds three more recent studies. The table shows that removal of energy subsidies could have substantial positive effects in Russia in terms of the impact on both local air pollution and climate change. It is likely the economic impacts would be positive as well as the Russian economy adjusts to world energy prices. The other studies reviewed in the table show the impact of removing various subsidies for energy on the production of carbon dioxide; for the cases examined, the impacts are all positive. ${ }^{22}$

This brief review of subsidies reveals that many do more good than harm in terms of their environmental impact. Many also encourage excessive use of particular energy sources, such as the consumption of oil in Iran or Russia. More research is needed to understand better the aggregate impacts of subsidies on the environment and energy security. In addition, more research is

\footnotetext{
${ }^{20} \mathrm{~A}$ question worth exploring is how the removal of energy subsidies for countries that are likely to be significant participants in a climate change agreement, such as India and China, would affect emissions of carbon dioxide.

${ }^{21}$ OECD (2005) provides an overview of environmental harmful subsidies in the OECD.

22 It is possible to imagine removal of specific energy subsidies, say for oil or gas, that could result in higher levels of carbon dioxide emissions if there were fuel switching to coal.
} 
needed on the efficiency gains (or losses) associated with removing subsidies.

D. Vehicle Regulation

This section reviews some important themes in vehicle regulation and examines the potential for efficiency improvements. We find that there is evidence that changes in regulatory approaches and the choice of regulatory targets could result in large efficiency gains. Furthermore, the use of less conventional instruments, such as congestion pricing, holds out considerable promise.

There are numerous automobile externalities, with local and global air pollution, congestion and traffic accidents being the most important ones. ${ }^{23}$ In all these cases, there is a plausible justification for some kind of regulatory or legal action because individuals may not otherwise take into account the full social costs of their actions (Coase, 1960; Posner, 1973).

The damages associated with motor vehicle travel can be substantial. In the U.S., for example, there were about 31 million accidents in 2000, which resulted in about 42 thousands fatalities and total injury costs of about $\$ 433$ billion (Parry et al., 2007, p. 382). Light duty vehicles also account for a fifth of U.S. carbon dioxide emissions (U.S. Department of Energy, 2006).

Vehicles are highly regulated in most parts of the developed world, and, increasingly in the developing world. Motor fuels, such as gasoline, are also taxed, sometimes heavily. Almost all countries

\footnotetext{
${ }^{23}$ Strictly speaking, these market failures arise only when there are externalities. Thus, for example, if an individual has an accident that hurts only himself or his vehicle, but does not increase the risk to someone else of having an accident, this should not be counted as an externality. Other externalities include oil dependency, noise, highway maintenance costs, urban sprawl, parking subsidies, and improper disposal of vehicles (Rothengatter, 2000; Parry et al., 2007).
} 
have significant taxes on fuel, ranging from $\$ .4 /$ gal (US) to $\$ 3.5 / \mathrm{gal}$ (UK) (Parry et al., 2007).

Most countries also have vehicle emission standards. In the U.S., for example, there are tailpipe standards that limit the number of grams-per mile of hydrocarbons, nitrogen oxides and carbon monoxide for new vehicles. Those standards have been significantly tightened since their introduction in the 1970 Clean Air Act and will eventually limit new vehicle emission rates to between 0.8-5.0 percent of their pre-1970 rates (Parry et al., 2007). An ex-post study of the Clean Air Act from 1970-1990 by the EPA suggest that benefits exceeded costs with a very high probability (U.S. Environmental Protection Agency, 1997). ${ }^{24}$ The European Union has similar legislation, and many developing countries model their standards after the U.S. or EU (Timilsina and Dulal, 2009). Enforcement of standards varies across regions and countries. In developing countries, enforcement is often relatively weak due to the lack of resources (Timilsina and Dulal, 2009).

Fuel economy standards for vehicles are popular in a number of developed countries, such as the U.S. and many member countries of the European Union. The U.S. has set its standard for cars at 27.5 miles per gallon since the mid 80 s. Light duty fuel economy standards have recently been revised so that they will gradually reach 35 miles per gallon by 2016. Economists have sometimes been critical of fuel economy standards because they can have some pernicious effects. For example, they raise the price of new vehicles, thus encouraging people to hold on to their older cars longer, which typically pollute more (Gruenspecht, 1982). Fuel economy standards also lower the cost per mile of driving.

\footnotetext{
${ }^{24}$ Note that the EPA study does not explicitly calculate benefits from tighter emission standards for automobiles, but only provides aggregate estimates for mobile and stationary sources. The magnitudes suggest that the regulation of mobile sources by itself would have passed a benefit-cost test (Parry et al., 2007).
} 
There is much evidence that fuel economy standards are not cost-effective compared with other approaches, such as gasoline taxes (see Table 3). For example Austin and Dinan (2005) find that the costs of reducing fuel consumption by $10 \%$ can be achieved with a gas tax at roughly $35 \%$ of the costs of comparable CAFE standards. Kleit (2004) finds that the costs of achieving energy savings from tightening CAFE standard by 3 miles per gallon are 14 times as great as those associated with a gas tax that achieves comparable energy savings. West and Williams (2005) argue that distortions created by existing taxes on labor further increase the attractiveness of gas taxes over CAFE. They estimate that these distortions increase the marginal cost of CAFE by about $60 \%$ compared with a situation with no preexisting labor taxes.

Gas taxes are a better instrument than fuel economy standards for reducing energy consumption in large part because gas taxes directly discourage fuel use by raising the price. However, gas taxes are rarely set to maximize welfare gains with respect to various energy and environmental externalities (see Table 3). Parry and Small (2005) find that increasing U.S. gas taxes from $\$ .40 /$ gal to $\$ 1 /$ gal would yield welfare gains equal to $7.4 \%$ of initial pre-tax fuel expenditures; decreasing UK gas taxes from $\$ 2.8 /$ gal to $\$ 1.34 /$ gal would yield welfare gain equal to $23 \%$ of pre-tax gasoline expenditures.

Gas taxes are not without their problems. In particular, they are an imperfect mechanism for addressing local air pollution externalities, traffic congestion and accidents, which are all more closely related to miles driven than to the amount of fuel used. Estimates of the externalities related to miles driven suggest that they are an order of magnitude higher than externalities related directly to fuel use, mainly greenhouse gas emissions (Parry, 2005). Researchers have examined a number of other instruments that 
could be used to increase efficiency significantly. These include taxes on vehicle miles traveled, pay as you drive insurance, and congestion charges.

Both taxes on vehicle miles traveled and pay as you drive insurance are motivated by the observation that externalities related to miles driven are quantitatively larger than externalities related to fuel use (Parry, 2005). Parry and Small (2005) analyze whether a fuel tax or a tax on vehicle miles traveled would achieve higher net benefits. They find that a tax on vehicle miles traveled yields much higher benefits for the U.S. and the UK, equivalent to an increase in welfare of about 27 percent of pre-tax gas expenditures in the respective countries (Parry and Small, 2005, p. 1285). An adjusted insurance system for automobiles could have a similar effect to a tax on vehicle miles traveled, but might face less political resistance. In such a scheme the current lump sum insurance premiums would be replaced by rates that depend on miles driven and other characteristics of drivers, such as age, crash record and region of residence. Parry (2005) estimates welfare gains of using this modified insurance would be much larger than welfare gains from an increase in the gasoline tax. It might also face less political resistance.

Another innovative policy instrument is congestion charges, which have been implemented in London and Singapore. In these cities, driving through designated areas is subject to a charge. The congestion charge in London is deemed to be a success today, both in terms of its effect on traffic within the designated areas and economic welfare. Vehicle miles driven within the designated areas was reduced by 12 percent in the first year alone (Leape, 2006, p. 165). A preliminary assessment of the social costs and benefits of the charge suggests annual net benefits of 67 million GBP in 2005 prices (Leape, 2006, p. 172). At the same time, the London scheme 
is fairly simple. For example, it does not change prices based on real-time congestion data, something that is currently being investigated in Singapore (Belson, 2008).

This brief review of vehicle regulation suggests that there is great potential for efficiency gains. We think it is fair to say that the lessons from environmental and resource economics have had less of an impact in this area than in the regulation of pollution from stationary sources, such as power plants.

\section{Implementing More Efficient Environmental and Energy policy}

The previous review of policies suggested that many energy and environmental policies are not economically efficient, though some improve on efficiency relative to the status quo. This is not terribly surprising, given that politics plays a large role in policy choice and economic efficiency is not widely accepted as an overarching objective for particular policies. Still, we think it is worth exploring how to make policies more economically efficient in the real world. The reason is that more efficient policies will generally expand the size of the economic pie. This larger pie can then, in theory, be distributed in ways that make many segments of the population better off.

We focus on two key factors affecting the implementation of more efficient policy. One is politics and the second is ideas. In general politics constrains the choice set in ways that reduce efficiency. In contrast, ideas can expand the choice set in ways that sometimes promote efficiency. Finally, we consider some factors that could promote the development of more efficient environmental and energy policies.

\section{A. Politics Affects Policy}

Economists and political scientists rely heavily on interest group theory to help explain why and how regulatory policies are 
promulgated. They also rely on theories of voting that emphasize the importance of the median voter (Downs, 1957). Noll (1999) summarizes some key aspects of interest group theory. The basic idea is that regulation is used primarily as a mechanism for transferring benefits from groups that are less politically powerful to those that are more powerful. The extent to which particular interest groups influence the political process is affected by the expected costs and benefits from organizing politically and the distribution of those benefits across groups and within groups (Olson, 1971). Many groups may find it difficult to organize because of problems with free-riding.

Reform is supposed to take place when there are changes in the relative costs and benefits of regulation, or when the relative influence of interest groups changes (see, e.g., Becker, 1983). The capture theory of regulation, put forward by some economists and political scientists, represents a case where the benefits to one interest group are concentrated (e.g., the trucking industry), and the costs to the public at large are diffuse (Bernstein, 1955; Stigler, 1971; Peltzman, 1976). ${ }^{25}$ Interest group theory explains some regulatory situations well, particularly when certain industries are protected. It does less well in explaining certain kinds of deregulation, such as the deregulation of the airlines (Levine, 1987).

Keohane, Revesz and Stavins (1998) use elements of political economy theory to suggest a general theory of instrument choice for the environment (see also Buchanan and Tullock, 1975; Dietz and Vollebergh, 2002). They suggest that there is a supply and demand for different policy instruments. Legislators supply political

\footnotetext{
${ }^{25}$ There may also be asymmetries in information between the concentrated group and the public; the latter often is not aware of the costs of an intervention, while the former might have very detailed knowledge about the cost of regulation that is specific to its area of operation.
} 
support for different instruments, which meets the demands of different interest groups and voters.

The theories used to examine the political economy of regulation are not always very clear about when more efficient policies are likely to emerge. However, interest group theory can be applied in different settings to develop some useful insights. For example, in an environment where politicians have less room to maneuver on fiscal policy, we can expect to see more regulation as a substitute. As regulation becomes more pervasive and unwieldy, it presents an opportunity for powerful groups adversely affected by regulation to try to change the status quo (Becker, 1983; Noll, 1999). Whether such regulation will be efficient in an economic sense, or more efficient than current policy, is not completely clear. As discussed below, economic analysis can help move the process toward more efficient outcomes by highlighting inefficiencies in particular regulations and processes, and designing more efficient alternatives.

General theories of political economy have been applied to show why certain inefficient elements of environmental and energy policy persist. For example, Ackerman and Hassler (1981) explain how Congress used the legislative process to protect certain constituencies. In particular, they argue that both the economy and environment were losers as a result of the highly prescriptive 1977 Clean Air Act Amendments, which required that new power plants install scrubbers to help protect certain coal mining jobs. The theme of regulating new sources more stringently than existing sources has been persistent in environmental policy, even though there is little or no economic justification. When allowance trading was introduced in 1990 to reduce sulfur dioxide emissions, the more stringent regulation of new sources was not relaxed, even though it would not have affected the overall level of sulfur dioxide emissions. 
A good example of how politics can influence the process of designing environmental policy is illustrated by recent U.S. efforts to address climate change using marketable permits. A key hope of President Obama's initial budget proposal had been to generate significant revenues from auctioning $\mathrm{CO}_{2}$ emission permits (Office of Management and Budget, 2009, p. 21). The Waxman-Markey bill (H.R. 2454) that ultimately passed the House of Representatives substantially reduced the revenue generated by allocating large fractions of the permits for free to various entities. This reflected the political reality that more political support for the bill could be garnered by giving the permits away to preferred constituencies in the early years (Pew Center on Global Climate Change, 2009). In addition, the bill contains some highly regulatory features that will unnecessarily increase costs (Schoenbrod and Stewart, 2009; Stavins, 2009).

There are three key points to be gleaned from this example related to equity and efficiency. First, the marketable permit approach for addressing climate change seems to be popular, in part, because politicians have some control over defining winners and losers from such a policy. Second, it appears that the President and the House of Representatives have different preferences regarding equity and efficiency. In this case, the President appears to have been more supportive of auctions than the House, perhaps because of a greater concern with deficits. Third, the House bill reveals that distributing permits is only one way of making tradeoffs between equity and efficiency. Direct regulation is also important. ${ }^{26}$

${ }^{26}$ It remains to be seen where whether climate legislation will pass in the US anytime soon. 
More than a half century ago, Richard Weaver wrote a book entitled Ideas Have Consequences (Weaver, 1948). Weaver was right. Think of some of the more influential economic thinkers ranging such as Smith, Marx, Keynes and Friedman. Keynes, in fact, stated that “...Practical men, who believe themselves to be quite exempt from any intellectual influences, are usually the slaves of some defunct economist" (Keynes, 1964, p. 383).

George Stigler, an economics Nobel laureate, argued that a fundamental problem for economists is that they did not do enough applied benefit-cost analysis of different policy alternatives. He believed that a key impediment to getting more economically efficient policies selected was that policy makers did not have the information they needed to make economically efficient choices. Give them more and better information and one could expect more efficient policy choices (Stigler, 1965). A somewhat older and wiser Stigler modified his earlier view in an article entitled "The Theory of Economic Regulation" (Stigler, 1971). ${ }^{27}$

A key insight from the literature on ideas is that they affect general policy choices. We see this very clearly in the areas of energy policy and environmental policy. Consider the nowconventional policy tools of benefit-cost analysis and marketable permits. Both of these tools have been used frequently during the last two decades. In the case of benefit-cost analysis, it is now performed routinely for all major environmental, health and safety regulation in the United States (Hahn and Tetlock, 2008). Cass Sunstein, for example, has argued that we now live in a "costbenefit state" (Sunstein, 2002).

27 This article relied on interest group theory to suggest why many aspects of regulation are likely to be "captured" by well-organized interest groups. 
In the case of marketable permits, they were embraced in the 1990 Clean Air Act amendments in the allowance trading program aimed at reducing sulfur dioxide (Stavins, 1998). There have also been a number of other applications including the trading of water rights in selected regions, and the trading of leads credit to reduce the lead content in gasoline. ${ }^{28}$ To see precisely how ideas matter, it is instructive to consider the case of marketable permits for controlling pollution in more detail. Early researchers made two important points. First, that it is, in principle, possible to design a system of marketable permits that achieved any particular target at least cost (e.g., Crocker, 1966; Dales, 1968). This result depended on a number of factors, including measurement of the particular input or output, such as pollution, and a linear (or monotonic) relationship between pollution and damages (Montgomery, 1972). The second point was that the distribution of property rights would not impair the achievement of an efficient result under certain conditions. Indeed, this was one of the key insights in Coase's famous article, "The Problem of Social Cost" (1960). ${ }^{29}$

The idea of marketable permits took decades to move from the ivory tower and the classroom into practice. Students, some of whom later became key decision makers, were taught these ideas in undergraduate and graduate economics courses. This teaching provided a pathway for the diffusion of the ideas.

Economists continued to work on the theory and also explored how these concepts can and do work in practice (Tietenberg, 2006). Some applications did not work well, partly for political reasons. For example, early experience with market-based approaches in the United States led to uneasy compromises, which in some cases

\footnotetext{
${ }^{28}$ For a more detailed overview of various approaches, see Stavins (2003).

29 This insight was particularly important for politicians making decisions about transferring wealth among groups and individuals. It allowed them to design a program where they could exert control over the distributional outcome while still promoting efficiency.
} 
sacrificed both cost savings and environmental quality (Liroff, 1980). Still, politicians, policy makers, and academics appear to have learned from these experiences.

The allowance trading scheme for sulfur dioxide, while not perfect in design or execution, represents a major advance over some of the earlier trading schemes. It also provides some important lessons for the design of a marketable permit system for reducing greenhouse gas emissions (Stavins, 1998). The trading scheme came into being, in part, because politicians could decide who received the revenues from the permits. They could also tailor the law in ways that made it more politically palatable, such as continuing to regulate new sources more stringently than old sources.

While the politics are somewhat different because greenhouse gas emissions are a global problem, the attractiveness of the idea is similar. It can allow politicians to address some difficult distributional issues in a more efficient manner (Stavins, 2007).

In summary, new ideas in the form of policy tools and new policy designs have the potential to improve efficiency greatly in energy and environmental policy. In addition, the demonstrated effectiveness of these ideas can affect their diffusion. But new, more efficient, policy designs are not in themselves sufficient for generating better policies because of constraints imposed by politics and the administrative process.

\section{Factors that Could Help Contribute to More Efficient Policy}

Academics, and economists in particular, can pursue both research and advocacy if they are interested in promoting more efficient policies. We suggest three ways in which research can promote efficiency: analyzing the benefits and costs of different policies, designing mechanisms for improving efficiency by 
improving information and changing the political landscape, and analyzing winning strategies that are likely to improve economic efficiency. In addition, we highlight the role that education and advocacy can play in promoting efficiency. The factors we identify are meant to address causes of government failure mentioned above-namely, that decision makers may not wish to pursue efficient policies, or they may not have access to good information.

Investigating the benefits and costs of different policies. For a decade, one of the authors (Hahn) ran a center aimed at holding regulators and lawmakers more accountable by doing both ex-ante and ex-post benefit-cost analysis of important regulatory issues. Such work is generally not glamorous and does not typically have a high payoff for academics because it rarely breaks new theoretical ground. It can, however, raise the cost to politicians and regulators of pursuing inefficient regulations by making these costs more transparent. We believe that more of this research should be encouraged by foundations, governments and the private sector.

Designing better tools for promoting efficiency. There has been, and continues to be major improvements in research in our understanding of how different economic instruments operate. For example, economists now have a deeper appreciation for how the use of revenues from a tax or permit system can affect the efficiency of that system (Bovenberg and Goulder, 1996). They also have a better understanding of how to design auction systems that are likely to work well for different kinds of problems (Klemperer, 2004). Furthermore, as noted above, there are refinements being made in our ability to measure different kinds of damages that could enhance the design of regulatory systems (Muller and Mendelsohn, forthcoming). These advances should be encouraged, as they can have great practical value. 
Law and economics scholars should also continue to investigate changes in the regulatory process that could help promote efficiency (e.g., Breyer, 1995). One major change that was implemented about three decades ago was to centralize regulatory oversight in the U.S. Over time, that regulatory process has become more transparent. Still, this transparency could be improved with standardized summaries of regulatory impact analyses.

In addition, there are concerns that such analyses may be compromised because they may not be independent; in some cases, the analysis may be "captured" by particular interests (Flyvbjerg, forthcoming). For example, if a regulatory agency wished to pursue a particular agenda, it may tailor its analysis to support that agenda. An alternative might be to have an independent agency, or independent analysts, perform the analysis. Developing and assessing the impact of such process changes is an important area where social scientists can contribute.

Helping to identify a winning strategy for enhancing efficiency. Any policy aimed at improving economic efficiency needs to be politically feasible to be implemented. Thus, it helps to understand the political forces that are likely to block such policy proposals and what it will take to effectively overcome those forces. Economists can help address this problem in two distinct ways. One is to understand the particular political motivation of different legislators. For example, a recent study by Cragg and Kahn (2009) suggests that conservative, poor areas have higher per-capita emissions than liberal, richer areas. They also show that representatives from these areas have a lower probability of voting for legislation that reduces carbon emissions.

Another way economists can help is by estimating what it will take to make certain interest groups at least as well off as they are under the status quo. There is a growing, literature, for example, 
that looks at the fraction of permits that needs to be allocated to industry in general, or specific industries, to make them at least as well of under the new regulatory regime as the status quo. This literature recognizes that distributing the permits for free can help buy the support of some key industries that otherwise might oppose the economic instrument. Allocating all permits for free, however, would likely overcompensate the regulated sector, creating large windfall profits for firms, such as occurred in the first phase of the EU ETS (Hepburn et al., 2006). Goulder et al. (2009) find that roughly 13 percent of freely allocated emission allowances would compensate firms under a cap-and-trade program in a profit neutral way for a emissions cap profile that matches the proposed Waxman-Markey bill. Burtraw and Palmer (2008) find that the U.S. electricity sector would require only 6 percent of the total value of allowances to be at least as well off under regulation.

This literature is particularly important in light of government's increasing interest in trying to keep the revenues from marketable permits to address budgetary shortfalls. As noted above, in the case of U.S. climate policy, it is unclear to which extent permits will be auctioned if a climate bill eventually becomes law. The nature of the actual revenue flows from economic instruments should be taken into account by academics and policy makers in the design of feasible and efficient instruments. Hahn (2009) notes that revenues from environmental taxes and auction revenues from permits are often allocated inefficiently, and such inefficiencies could arise in future applications.

Reducing costs to voters of becoming informed. As Downs pointed out many years ago, voters quite rationally remain uninformed about many issues given the high cost of becoming informed (Downs, 1957). Many of the issues related to more 
efficient policy design are highly technical, and some require a fair amount of economics.

Economists could help reduce the cost to voters by making economics more accessible to both students at the high school and college levels. If the average voter understood basic concepts related to economics, such as opportunity cost and no-free lunch, it would be easier for them to appreciate the importance of considering economic efficiency in the design of policy.

Economists could also promote a more informed discussion by making some of their writing and arguments more accessible to the public. Journals, such as the Economists' Voice, have been helpful in this regard, but there is still little professional payoff to academic economists for engaging in this activity.

Finally, where there is consensus among economists on the importance of using tools like benefit-cost analysis and marketable permits, this consensus should be effectively communicated to interested elites and the public at large. One way of doing this is through issuing jointly authored documents that are published in accessible places (e.g., Arrow et al., 1996; Arrow et al., 2008; Walker et al., 2009).

Lobbying for efficiency. Years ago, Steven Kelman wrote a wonderful book about the lack of understanding of how pollution taxes actually work among Capitol Hill staffers (Kelman, 1981). In that book, he argued that economists who endorse such approaches need to become "lobbyists for efficiency" if they wish to see their ideas put into practice.

We believe Kelman was right. Many academic economists are not comfortable with this idea because they feel it is either beneath them or may sacrifice their academic objectivity. While we understand their views, we believe that people should stand up for 
what they believe in. For example, if economists believe that benefit-cost analysis should be more widely used, they might want to consider endorsing mechanisms that allow for the more widespread use of such analysis. One such mechanism is a requirement that benefit-cost analysis of regulations be reviewable in a court of law.

Economists might also want to market their views on the importance of using good economic analysis to politicians who are more likely to be supportive-most notably national presidents and prime ministers. These officials, who represent large and broad constituencies, are more likely to take a societal perspective than politicians who represent narrower constituencies.

Economists should also be prepared to seize the moment when it arises to trumpet the findings of their analysis for purposes of policy design. Ethanol provides a good example. Many economists have suggested that corn-based ethanol should not be subsidized or protected from imports (Wolak, 2007). The main reason is that such support is not justified on benefit-cost grounds. When interest groups, such as beef producers, are adversely affected by government support for corn growers, this situation may present an opportunity to advance policies that increase economic efficiency in this area.

There are two general points here. First, it is difficult to predict when a benefit-cost analysis of something like ethanol will be policy relevant. Second, when the issue does become salient, academic economists can help by taking on lobbying for efficiency.

\section{Conclusion and Areas for Future Research}

This paper provided a selective review of the economics and political science literature on energy and environmental policy. We focused primarily on regulatory policies, mostly in developed 
countries. We found that many energy and environmental policies likely do more good than harm, but many do not. Furthermore, many of these policies do not come close to maximizing net economic benefits. A review of the literature in political economy provided compelling reasons for why energy and environmental regulation is rarely efficient.

Economists have already had some impact on energy and environmental policy. Examples include the development and implementation of benefit-cost analysis and the market-based approaches for environmental protection. We suggested a number of ways that economists might facilitate the implementation of more efficient energy and environmental policies in the future. These included doing more analysis of the benefits and costs of different policies, designing better tools for promoting efficiency, reducing the costs to voters of becoming informed, and lobbying for efficiency. Political scientists and economists could also help identify approaches that would be politically feasible in designing more efficient policies.

While perhaps less apparent, economists have had an important impact on framing parts of the climate change debate. Economic modeling has provided insight into setting reasonable goals for climate policy, efficient means for achieving particular goals, and the design of mechanisms for achieving the goals that may be politically feasible. Clearly, much more needs to be done in designing and implementing sensible policies, but economists continue to have an impact.

There are several areas that could benefit from research. First, our review of subsidies suggested that little is known about the overall effect of removing subsidies related to energy and the environment. Research in this area may motivate some decision makers to take a closer look at the economic and social impacts of 
various subsidies. Second, our analysis does not cover the impact of various regulatory instruments on innovation. Innovation is an important driver of economic welfare, and understanding better how various forms of regulation affect energy and environmental innovation is important (see, e.g., Popp, 2002). Third, most research covers the U.S., and to a lesser extent, Europe. More research on other areas of the world would be useful. Finally, it would be valuable to have a more complete theory about the conditions under which more efficient policies will emerge in the energy and environmental arenas. Political economy provides some general guidance, but we know little about the specifics of what drives policy changes that promote efficiency. 


\section{Bibliography}

Ackerman, B. and W. T. Hassler (1981). Clean Coal/Dirty Air: or How the Clean Air Act Became a Multibillion-Dollar Bail-Out for High-Sulfur Coal Producers Yale University Press.

Arrow, K. J., M. L. Cropper, G. C. Eads, R. W. Hahn, L. B. Lave, R. G. Noll, P. R. Portney, M. Russell, R. Schmalensee, V. K. Smith and R. N. Stavins (1996). "Is there a role for benefitcost analysis in environmental, health, and safety regulation?" Science 272(5259): 221-221.

Arrow, K. J., R. Forsythe, M. Gorham, R. Hahn, R. Hanson, J. O. Ledyard, S. Levmore, R. Litan, P. Milgrom, F. D. Nelson, G. R. Neumann, M. Ottaviani, T. C. Schelling, R. J. Shiller, V. L. Smith, E. Snowberg, C. R. Sunstein, P. C. Tetlock, P. E. Tetlock and H. R. Varian (2008). "The Promise of Prediction Markets." Science 320(5878): 877-878.

Austin, D. and T. Dinan (2005). "Clearing the air: The costs and consequences of higher CAFE standards and increased gasoline taxes." Lournal of Environmental Economics and Management 50: 562-582.

Barrett, S. (1994). "Self-Enforcing International Environmental Agreements." Oxford Economic Papers 46(Special I ssue on Environmental Economics): 878-894.

Baumol, W. J. and W. E. Oates (1988). The theory of environmental policy. Cambridge, Cambridge University Press.

Becker, G. S. (1983). "A Theory of Competition Among Pressure Groups for Political Influence " Quarterly Journal of Economics 98(3): 371-400.

Becker, G. S. and C. B. Mulligan (2003). "Deadweight Costs and the Size of Government." Lournal of Law and Economics XLVI : 293-340.

Belson, K. (2008). Importing a Decongestant for Midtown Streets. The New York Times. New York.

Bernstein, M. H. (1955). Regulating Business by Independent Commission. Princeton, Princeton University Press.

Bovenberg, A. L. and L. H. Goulder (1996). "Optimal Environmental Taxation in the Presence of Other Taxes: General-Equilibrium Analyses." The American Economic Review 86(4): 985-1000.

Breyer, S. (1995). Breaking the Vicious Circle: Toward Effective Risk Regulation. Cambridge, Harvard University Press.

Buchanan, J. M. and G. Tullock (1975). "Polluters' Profits and Political Response: Direct Controls versus Taxes " American Economic Review 65(1): 139-147.

Burtraw, D. and K. Palmer (2008). "Compensation rules for climate policy in the electricity sector." Lournal of Policy Analysis and Management 27(4): 819-847. 
Carlson, C., D. Burtraw, M. Cropper and K. L. Palmer (2000). "Sulfur Dioxide Control by Electric Utilities: What Are the Gains from Trade?" Lournal of Political Economy 108(6): 1292-1326.

Coase, R. H. (1960). "The Problem of Social Cost." Lournal of Law and Economics 3(1): 1-44.

Cohen, L. R. and R. G. Noll, Eds. (1991). The Technology Pork Barrel. Washington, D.C., Brookings Institution Press

Cragg, M. I. and M. E. Kahn (2009). Carbon Geography: The Political Economy of Congressional Support for Legislation Intended to Mitigate Greenhouse Gas Production. Working Paper, NBER.

Crocker, T. D. (1966). The Structuring of Atmospheric Pollution Control Systems. The Economics of Air Polllution. H. Wolozin. New York, W.W Norton \& Co: 61-86.

Dales, J. H. (1968). Pollution, Property and Prices. Toronto, University of Toronto Press.

Dietz, F. J. and H. R. J. Vollebergh (2002). Explaining instrument choice in environmental policies. Handbook of Environmental and Resource Economics. J. C. J. M. van den Bergh. Cheltenham, Edward Elgar Publishing: 339-351.

Downs, A. (1957). An Economic Theory of Democracy. New York, Harper.

Ellerman, A. D. and B. K. Buchner (2008). "Over-Allocation or Abatement? A Preliminary Analysis of the EU ETS Based on the 2005-06 Emissions Data." Environmental and Resource Economics 41: 267-287.

Ellerman, A. D., P. L. Joskow, R. Schmalensee, J.-P. Montero and E. M. Bailey (2000). Markets for Clean Air: The U.S. Acid Rain Program. New York, Cambridge University Press.

Flyvbjerg, B. (forthcoming). "Survival of the Un-fittest: Why the Worst Infrastructure Gets Built -- and What We Can Do About It." Oxford Review of Economic Policy.

Freeman III, A. M. (2002). "Environmental Policy since Earth Day I: What Have We Gained?" Lournal of Economic Perspectives 16(1): 125-146.

Frondel, M., N. Ritter and C. M. Schmidt (2008). "Germany's solar cell promotion: Dark clouds on the horizon." Energy Policy 36(11): 4198-4204.

Goulder, L. H., M. A. C. Hafstead and M. Dworsky (2009). I mpacts of Alternative Emissions Allowance Allocation Methods under a Federal Cap-and-Trade Program. NBER Working Paper.

Graham, J. D. (2008). "Saving Lives through Administrative Land and Economics." University of Pennsylvania Law Review 157(2): 395-540. 
Gruenspecht, H. K. (1982). "Differentiated Regulation: The Case of Auto Emissions Standards." American Economic Review 72(2): 328-331.

Guasch, J. L. and R. W. Hahn (1999). "The Costs and Benefits of Regulation: Implications for Developing Countries." World Bank Research Observer 14(1): 137-158.

Hahn, R. W. (2000). Reviving Regulatory Reform: A Global Perspective. Washington, D.C., AEI-Brookings J oint Center for Regulatory Studies.

Hahn, R. W. (2009). "Greenhouse Gas Auctions and Taxes: Some Political Economy Considerations." Review of Environmental Economics and Policy.

Hahn, R. W. and G. L. Hester (1989). "Marketable permits: Lessons for theory and practice." Ecology Law Quarterly 16: 361-406.

Hahn, R. W., R. K. Lutter and W. K. Viscusi (2000). Do Federal Regulations Reduce Mortality? Washington, D.C., AEIBrookings J oint Center for Regulatory Studies.

Hahn, R. W. and P. C. Tetlock (2008). "Has Economic Analysis Improved Regulatory Decisions?" Lournal of Economic Perspectives 22(1): 67-84.

Harrington, W., R. D. Morgenstern and P. Nelson (2000). "On the Accuracy of Regulatory Cost Estimates." Lournal of Policy Analysis and Management 19(2): 297-322

Helm, D. (2009). EU climate change policy - a critique. Climates of Change: Sustainability Challenges for Enterprise. Oxford, UK, Smith School of Enterprise and the Environment, University of Oxford.

Hepburn, C., K. Neuhoff, M. Grubb, F. Matthes and M. Tse (2006). "Auctioning of EU of EU ETS Phase II allowances: why and how?" Climate Policy 6(1): 137-160.

International Energy Agency (2008). World Energy Outlook 2008. Paris, International Energy Agency.

Jaffe, A. B., R. G. Newell and R. N. Stavins (2005). "A tale of two market failures: Technology and environmental policy." Ecological Economics 54: 164-174.

Kelman, S. (1981). What price incentives?: economists and the environment, Auburn House.

Keohane, N. O. (2006). Cost Savings from Allowance Trading in the 1990 Clean Air Act: Estimates from a Choice-Based Model. Moving to Markets in Environmental Regulation: Lessons from Twenty Years of Experience. C. E. Kolstad and J. Freeman. New York, Oxford University Press.

Keohane, N. O., R. L. Revesz and R. N. Stavins (1998). "The Choice of Regulatory Instruments in Environmental Policy." Harvard Environmental Law Review 22: 313-367.

Keynes, J. M. (1964). The General Theory of Employment, Interest, and Money. New York, Harcourt, Brace and World. 
Kishimoto, A., T. Oka and J. Nakanishi (2003). "The costeffectiveness of life-saving interventions in Japan. Do chemical regulations cost too much?" Chemosphere 53: 291299.

Kleit, A. N. (2004). "Impacts of Long-Range increases in the Fuel Economy (CAFE) Standard." Economic Inquiry 42(2): 279294.

Klemperer, P. (2004). Auctions: Theory and Practice. Princeton, Princeton University Press.

Leape, J. (2006). "The London Congestion Charge." Journal of Economic Perspectives 20(4): 157-176.

Levine, M. E. (1987). "Airline Competition in Deregulated Markets: Theory, Firm Strategy, and Public Policy." Yale Journal on Regulation 4: 393.

Liroff, R. A. (1980). Air pollution offsets: trading, selling, and banking, Conservation Foundation.

Montgomery, W. D. (1972). "Markets in Licenses and Efficient Pollution Control Programs." Lournal of Economic Theory 5: 395-418.

Morrall, J. F. (2003). "Saving Lives: A Review of the Record." Lournal of Risk and Uncertainty 27(3): 221-237.

Muller, A. and T. Sterner, Eds. (2006). Environmental Taxation in Practice. Hampshire, England, Ashgate Publishing Limited.

Muller, N. Z. and R. Mendelsohn (forthcoming). "Efficient Pollution Regulation: Getting the Prices Right." American Economic Review.

Noll, R. G. (1999). The Economics and Politcis of the Slowdown in Regulatory Reform. Washington, D.C., AEI-Brookings J oint Center for Regulatory Studies.

Nordhaus, W. (2008). A Question of Balance: Weighing the Options on Global Warming Policies. New Haven \& London, Yale University Press.

Nordhaus, W. and J. Boyer (2000). Warming the World: Economics Models of Global Warming.

OECD (2005). Environmental Harmful Subsidies. Challenges for Reform. Paris, Organisation for Economic Co-Operation and Development.

Office of Management and Budget (2009). A New Era of Responsibility. Renewing America's Promise. Washington, D.C., Office of Management and Budget.

Olson, M. (1971). The Logic of Collective Action: Public Goods and the Theory of Groups. Cambridge, Harvard University Press.

OMB (2008). Draft 2008 Report to Congress on the Benefits and Costs of Federal Regulations and Unfunded Mandates on State, Local and Tribal Entitites, Office of Management and Budget. 
Parry, I. W. H. (2005). "Is Pay-as-You-Drive Insurance a Better Way to Reduce Gasoline than Gasoline Taxes?" American Economic Review 95(2): 288-293.

Parry, I. W. H. and K. A. Small (2005). "Does Britain or the United States Have the Right Gasoline Tax?" The American Economic Review 95(4): 1276-1289.

Parry, I. W. H., M. Walls and W. Harrington (2007). "Automobile Externalities and Policies." Lournal of Economic Literature XLV: 373-399.

Pearce, D. W. (2003). Environmentally harmful subsidies: barriers to sustainable development. Environmentally Harmful Subsidies: Policy Issues and Challenges. OECD. Paris, Organisation for Economic Co-Operation and Development: 930.

Peltzman, S. (1976). "Toward a More General Theory of Regulation." Lournal of Law and Economics 19(2): 211-240.

Pew Center on Global Climate Change (2009). Distribution of Allowances under the American Clean Energy and Security Act (Waxman-Markey). Climate Policy Memo. Washington D.C., Pew Center on Global Climate Change.

Popp, D. (2002). "Induced Innovation and Energy Prices " American Economic Review 92(1): 160-180.

Portney, P. R. (1990). "Policy Watch: Economics and the Clean Air Act." Lournal of Economic Perspectives 4(4): 173-181.

Posner, R. A. (1973). Economic Analysis of Law. Boston, Little Brown.

Ramsberg, J. A. L. and L. Sjöberg (1997). "The Cost-Effectiveness of Lifesaving Interventions in Sweden." Risk Analysis 17(4): 467-478.

Rothengatter, W. (2000). External Effects of Transport. Analytical Transport Economics: An International Perspective. J. B. Polak and A. Heertje. Cheltenham, U.K. and Northampton, Mass., Elgar: 79-116.

Schelling, T. C. (1998). Costs and Benefits of Greenhouse Gas Reduction. Washington D.C., American Enterprise Institute Press.

Schoenbrod, D. and R. B. Stewart (2009). The Cap-and-Trade Bait and Switch: The climate bill in Congress is not the market solution the president promised. The Wall Street J ournal.

Stavins, R. N. (1998). "What Can We Learn from the Grand Policy Experiment? Lessons from $\mathrm{SO}_{2}$ Allowance Trading." Lournal of Economic Perspectives 12(3): 69-88.

Stavins, R. N. (2003). Experience with Market-Based Environmental Policy Instruments. Handbook of Environmental Economics. K.-G. Mäler and J. Vincent. Amsterdam, Elsevier Science. I : 355-435. 
Stavins, R. N. (2007). A U.S. Cap-and-Trade System to Address Global Climate Change. The Hamilton Project, Discussion Paper. Washington, D.C., The Brookings Institution.

Stavins, R. N. (2009). National Climate Change Policy: A Quick Look Back at Waxman-Markey and the Road Ahead. An Economic View of the Environment.

Stigler, G. J. (1965). "The Economist and the State " American Economic Review 55(1/2): 1-18.

Stigler, G. J. (1971). "The Theory of Economic Regulation " Bell Lournal of Economics and Management Science 2(1): 3-21.

Sunstein, C. R. (2002). The cost-benefit state: the future of regulatory protection, American Bar Association.

Tengs, T. O., M. E. Adams, J. S. Pliskin, D. G. Safran, J. E. Siegel, M. C. Weinstein and J. D. Graham (1995). "Five-Hundred LifeSaving Interventions and Their Cost-Effectiveness." Risk Analysis 15(3): 369 - 390.

Tengs, T. O. and J. D. Graham (1996). The Opportunity Costs of Haphazard Social Investments in Life-Saving. Risks, Costs, and Lives Saved: Getting Better Results from Regulation. R. W. Hahn. New York and Oxford, Oxford University Press.

Tietenberg, T. (2006). Emissions Trading: Principles and Practice. Washington, D.C., Resources for the Future.

Timilsina, G. R. and H. B. Dulal (2009). A Review of Regulatory Instruments to Control Environmental Externalities from the Transport Sector. Policy Research Working Paper. Washington, D.C., The World Bank.

Tol, R. S. J. (2008). "The Social Cost of Carbon: Trends, Outliers, and Catastrophes." Economics - the Open-Access, OpenAssessment E-Journal 2(25): 1-24.

Tol, R. S. J. (2009). "Intra-union flexibility of non-ETS emission reduction obligations in the European Union." Energy Policy 37(5): 1745-1752.

U.S. Department of Energy, E. I. A. (2006). Annual Energy Review 2005. Washington, D.C., U.S. Department of Energy.

U.S. Environmental Protection Agency (1985). Costs and Benefits of Reducing Lead in Gasoline: Final Regulatory Impact Analysis. Washington, D.C., U. S. Environmental Protection Agency, Office of Policy Analysis.

U.S. Environmental Protection Agency (1997). The Benefits and Costs of the Clean Air Act,1970 to 1990. Washington, D.C., U.S. Environmental Protection Agency.

van Beers, C. and A. de Moor (2001). Public Subsidies and Policy Failures: How Subsidies Distort the Natural Environment, Equity and Trade, and How to Reform Them. Cheltenham, UK, Edward Elgar.

Victor, D. G. (2009). On the Political Economy of Fossil Fuel Subsidies. 
Walker, B., S. Barrett, S. Polasky, V. Galaz, C. Folke, G. Engström, F. Ackerman, K. Arrow, S. Carpenter, K. Chopra, G. Daily, P. Ehrlich, T. Hughes, N. Kautsky, S. Levin, K.-G. Mäler, J. Shogren, J. Vincent, T. Xepapadeas and A. d. Zeeuw (2009). "Looming Global-Scale Failures and Missing Institutions." Science 325: 1345-1346.

Weaver, R. (1948). Ideas Have Consequences, University of Chicago Press.

Weitzman, M. L. (1974). "Prices vs. Quantities." The Review of Economic Studies 41(4): 477-491.

West, S. E. and R. C. Williams III (2005). "The Cost of Reducing Gasoline Consumption." American Economic Review 95(2): 294-299.

Winston, C. (1998). "U.S. Industry Adjustment to Economic Deregulation " Journal of Economic Perspectives 12(3): 89110.

Winston, C. (2006). Government Failure versus Market Failure. Washington, D.C., AEI-Brookings J oint Center for Regulatory Studies.

Wolak, F. A. (2007). An ethanol policy that benefits all Americans. Stanford Institute for Economic Policy Research Policy Brief. 


\section{Figures and Tables}

Figure 1: Estimates of the Total Annual Benefits and Costs of Major Federal Regulations:

1997-2007 (millions of 2001 dollars)

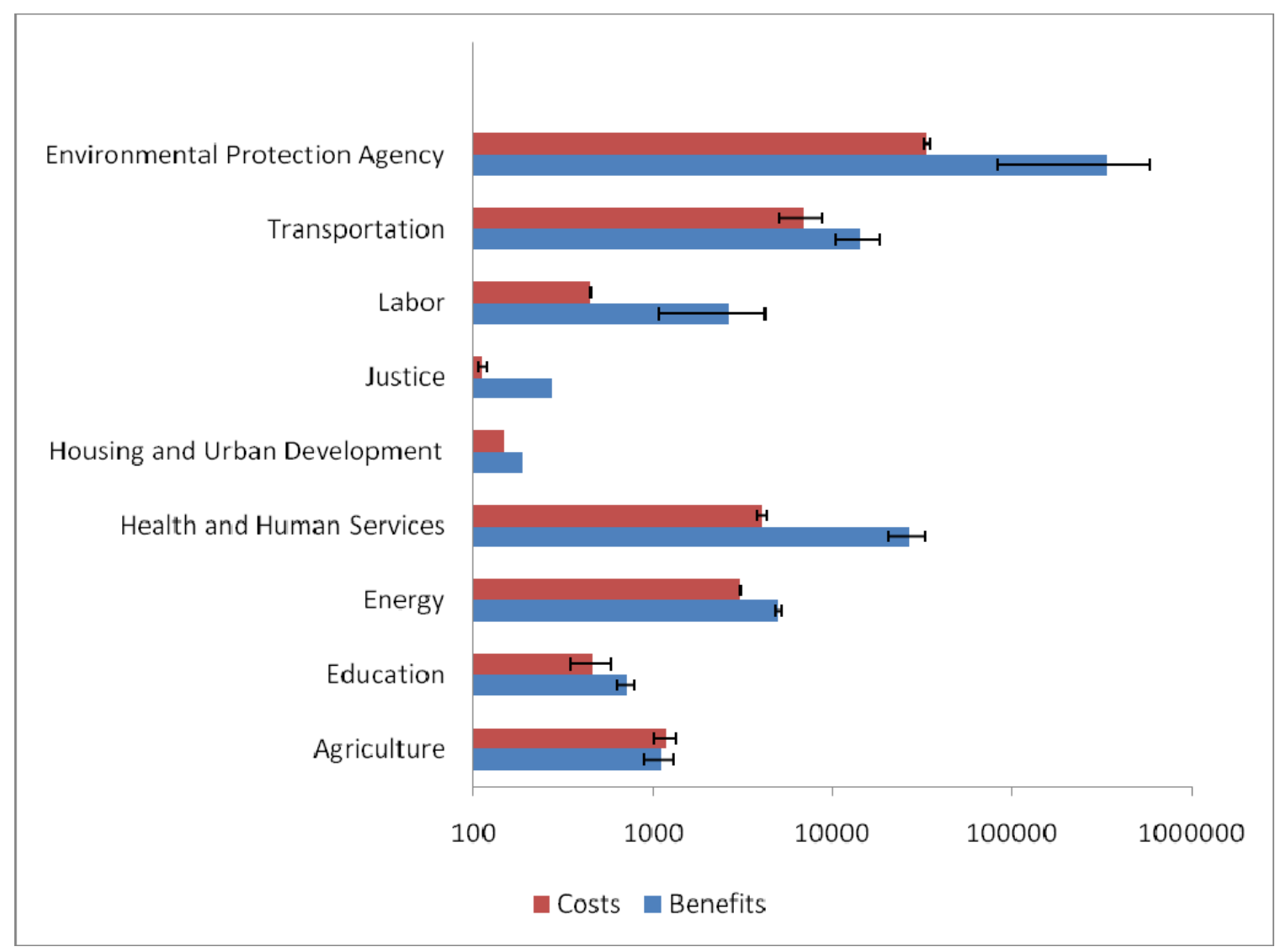

Source: Based on OMB (2008, p. 4, Table 1-1)

Notes: The OMB report only provides ranges, which are shown as error bars in the chart. We took the mean of the range for the central values. Note that horizontal axis uses a logarithmic scale and the origin starts at 100 million dollars. 
Figure 2: Cost Effectiveness of Safety, Toxin Control and Other Regulation. Cost per Statistical Life Saved (millions of 2002 dollars)

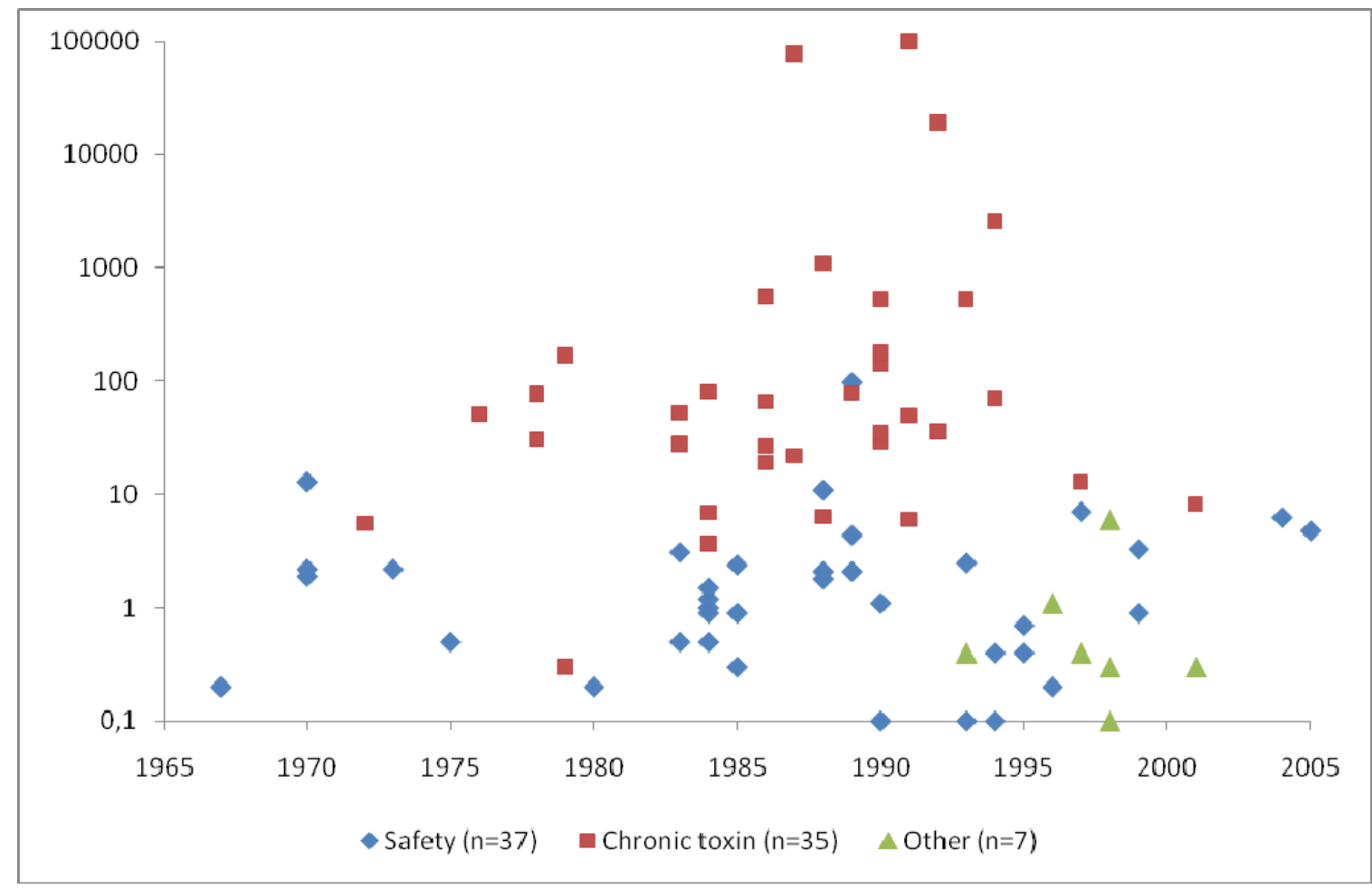

Source: Morrall (2003, pp. 231-232), as updated in Hahn and Tetlock (2008, p. 76) 
Figure 3: Cost Savings Associated with Using Marketable Permits to Address Different Environmental Problems

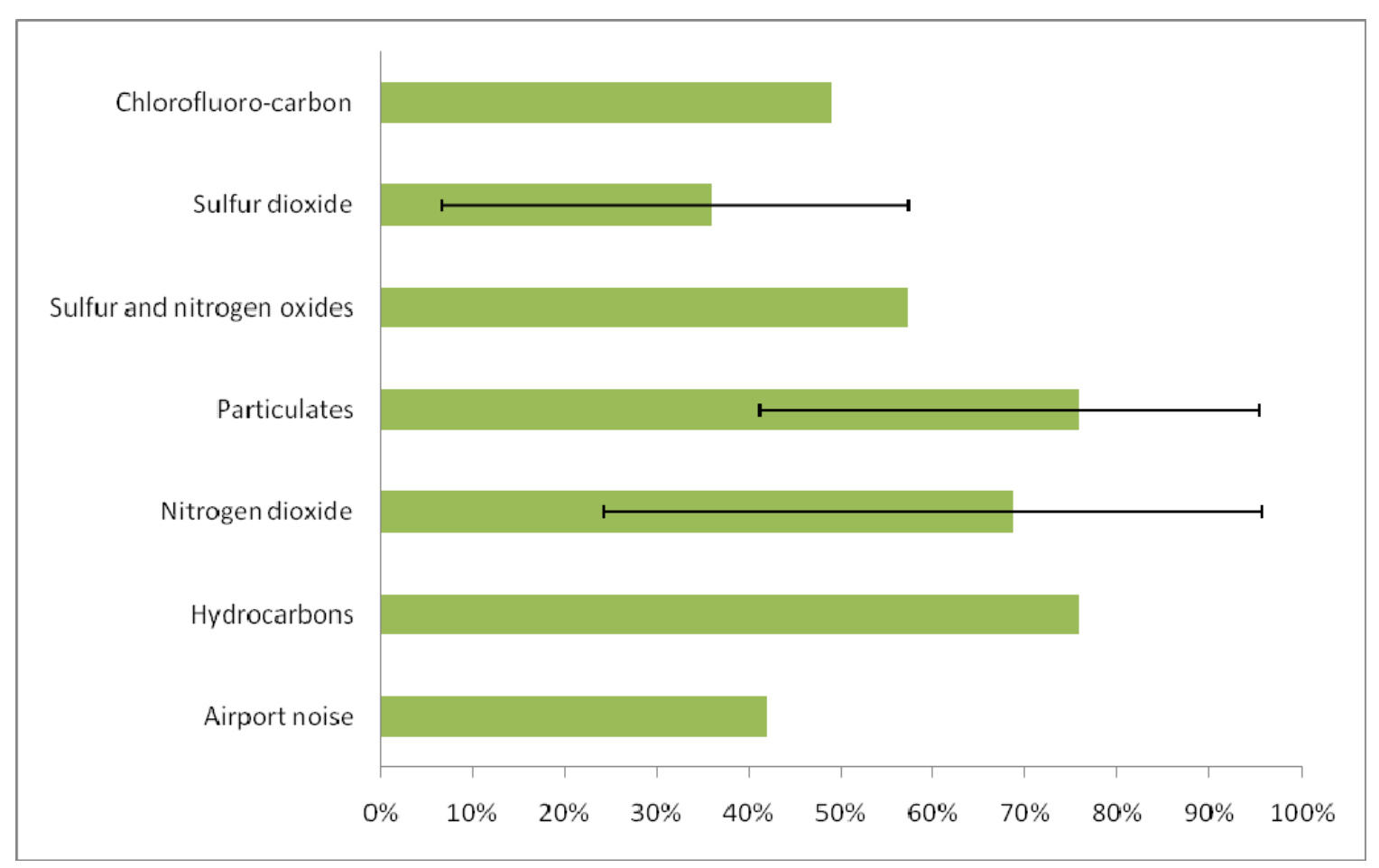

Source: Tietenberg (2006, pp. 58-59)

Notes: If there were more than on study, the green bar shows the mean of all studies and the error bars show the minimum and maximum value. 
Figure 4: Estimates of Annual World subsidies in 1994-1998 (USD billion)

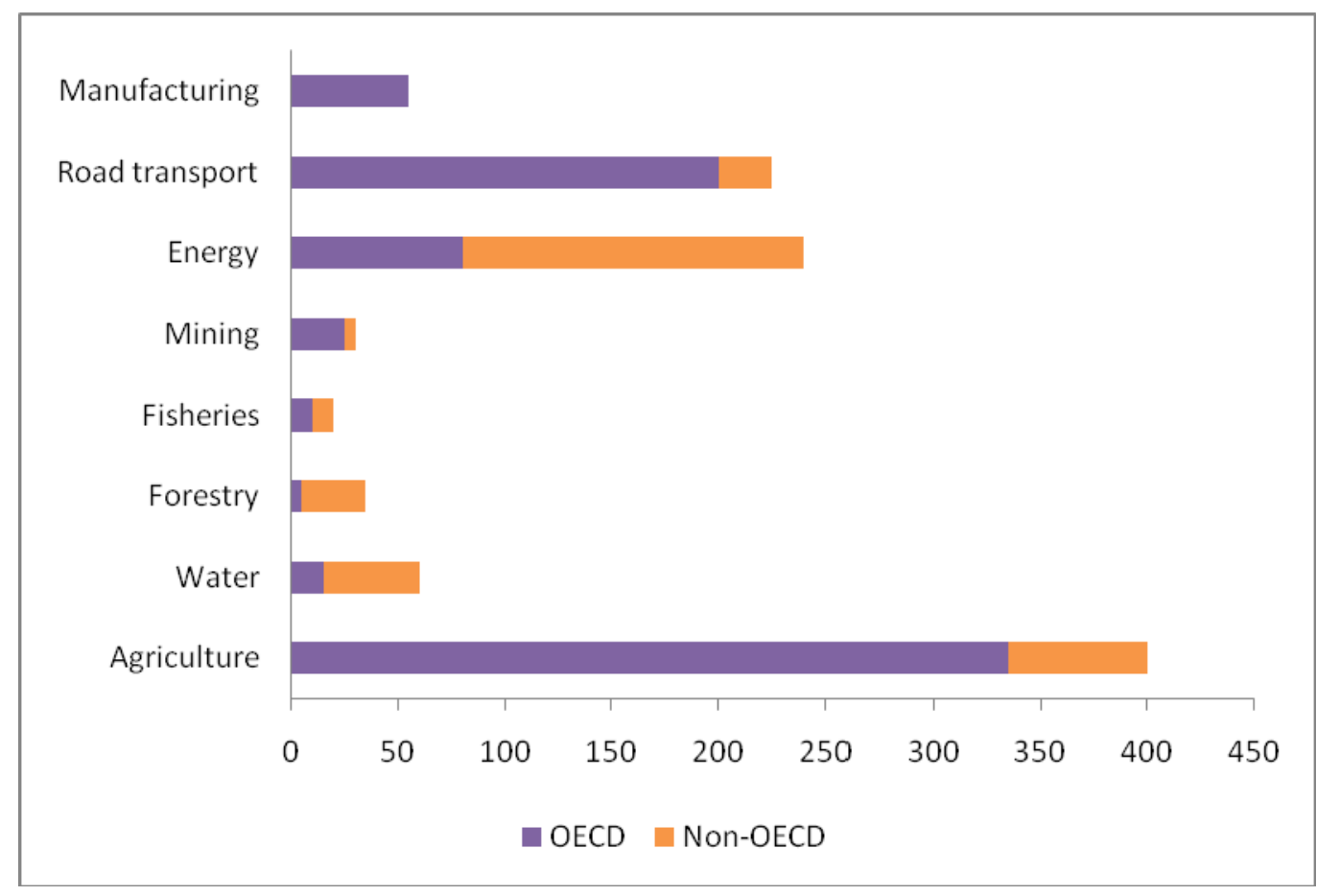

Source: van Beers and de Moor (2001, p. 32, Table 3.1) 
Table 1: Ex-post Studies of Marketable Permit Programs

\begin{tabular}{|c|c|c|}
\hline Study & Details & Impact estimate \\
\hline \multicolumn{3}{|c|}{$\mathrm{US} \mathrm{SO}_{2}$ trading program - cost savings } \\
\hline $\begin{array}{l}\text { Carlson et al. } \\
(2000)^{\mathrm{a}}\end{array}$ & $\begin{array}{l}\text { Compared to command } \\
\text { and control regime }\end{array}$ & $\begin{array}{l}\text { 1995: }-\$ 42 M \\
1996:-\$ 184 M\end{array}$ \\
\hline $\begin{array}{l}\text { Ellerman et al. } \\
(2000)^{\mathrm{b}}\end{array}$ & $\begin{array}{l}\text { Compared to command } \\
\text { and control regime }\end{array}$ & $\begin{array}{l}\text { 1995-9: \$506 M per } \\
\text { year }\end{array}$ \\
\hline \multirow[t]{2}{*}{ Keohane $(2006)^{c}$} & $\begin{array}{l}\text { Compared to command } \\
\text { and control regime }\end{array}$ & $\begin{array}{l}\text { 1995-9: } \$ 216-259 \mathrm{M} \\
\text { per year }\end{array}$ \\
\hline & $\begin{array}{l}\text { Compared to scrubber } \\
\text { regime }\end{array}$ & $\begin{array}{l}\text { 1995-9: \$2554 M per } \\
\text { year }\end{array}$ \\
\hline \multicolumn{3}{|c|}{ EU Emission Trading System - emission reductions } \\
\hline $\begin{array}{l}\text { Ellerman and } \\
\text { Buchner }(2008)^{d}\end{array}$ & EU ETS covered sectors & $\begin{array}{l}\text { 2005-6: } \\
\text { 50-100 Mton } \mathrm{CO}_{2} \text { per } \\
\text { year }\end{array}$ \\
\hline $\begin{array}{l}\text { Delarue, Voorspools, } \\
\text { D'haeseleer }(2008)^{\mathrm{e}}\end{array}$ & EU power sector & $\begin{array}{l}\text { 2005: } 88 \text { Mton } \mathrm{CO}_{2} \\
\text { 2006: } 59 \text { Mton } \mathrm{CO}_{2}\end{array}$ \\
\hline 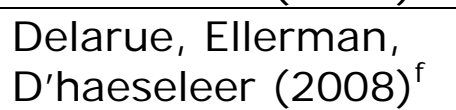 & EU power sector & $\begin{array}{l}\text { 2005: } 34 \mathrm{Mton} \mathrm{CO}_{2} \\
\text { 2006: } 19 \mathrm{Mton} \mathrm{CO}_{2}\end{array}$ \\
\hline $\begin{array}{l}\text { McGuinness and } \\
\text { Ellerman }(2008)^{g}\end{array}$ & UK power sector & $\begin{array}{l}\text { 2005: } 13-21 \mathrm{Mton} \mathrm{CO}_{2} \\
\text { 2006: } 14-21 \text { Mton } \mathrm{CO}_{2}\end{array}$ \\
\hline $\begin{array}{l}\text { Ellerman and } \\
\text { Feilhauer }(2008)^{\mathrm{h}}\end{array}$ & German power sector & $\begin{array}{l}\text { 2005-7: } 13-57 \text { Mton } \\
\mathrm{CO}_{2} \text { per year }\end{array}$ \\
\hline
\end{tabular}

Notes: All prices are in 2008 dollars.

${ }^{a}$ Based on econometrically estimated marginal abatement cost curves and cost minimizing assumption

${ }^{\mathrm{b}}$ Based on a calibrated model

${ }^{\mathrm{c}}$ Based on econometrically estimated model of abatement choices of electric utilities

${ }^{d}$ Based on trend extrapolation of real GDP growth and rate of decline in $\mathrm{CO}_{2}$ intensity

${ }^{\mathrm{e}}$ Based on simulation with the E-Simulate model

${ }^{f}$ Based on simulation with E-Simulate model that was calibrated to observed data from 2003 and 2004

${ }^{9}$ Based on econometrically estimated model of fuel switching behavior

${ }^{\mathrm{h}}$ Upper bound based on trend extrapolation of real GDP growth and rate of decline in $\mathrm{CO}_{2}$ intensity; lower bound based on simulations with the E-Simulate model 
Table 2: Environmental Effects of Subsidies

\begin{tabular}{|c|c|c|}
\hline Study & Nature of scenario & Environmental impacts \\
\hline \multirow{2}{*}{$\begin{array}{l}\text { Cristofaro et al. } \\
\text { (1995) } \\
\text { US }\end{array}$} & \begin{tabular}{|l|} 
Removal of USD 8.5 \\
billion energy subsidies
\end{tabular} & $\begin{array}{l}-10 \mathrm{mtC} \text { by } 2010 \\
-37 \mathrm{mtC} \text { by } 2035\end{array}$ \\
\hline & \begin{tabular}{|l|} 
Removal of USD 15.4 \\
billion energy subsidies
\end{tabular} & $-64 \mathrm{mtC}$ by 2010 \\
\hline $\begin{array}{l}\text { Gurvich et al. } \\
\text { (1995) } \\
\text { Russia }\end{array}$ & $\begin{array}{l}\text { Removal of energy } \\
\text { subsidies (effects in } \\
2010 \text { ) }\end{array}$ & $\begin{array}{l}76 \% \text { reduction in } \mathrm{TSP} \\
39 \% \text { reduction in } \mathrm{CO}_{2} \\
43 \% \text { reduction in } \mathrm{NO}_{x} \\
66 \% \text { reduction in } \mathrm{SO}_{x}\end{array}$ \\
\hline IEA (1999) & $\begin{array}{l}\text { Removal of consumer } \\
\text { subsidies in Russia, } \\
\text { China, and six other } \\
\text { countries }\end{array}$ & $16 \%$ reduction in $\mathrm{CO}_{2}$ \\
\hline $\begin{array}{l}\text { Larsen and Shah } \\
\text { (1994) }\end{array}$ & $\begin{array}{l}\text { Removal of world energy } \\
\text { subsidies of USD } 230 \\
\text { billion }\end{array}$ & $21 \%$ reduction in $\mathrm{CO}_{2}$ \\
\hline $\begin{array}{l}\text { GREEN in Michaelis } \\
\text { (1996b) }\end{array}$ & $\begin{array}{l}\text { Removal of global } \\
\text { subsidies of USD } 235 \\
\text { billion }\end{array}$ & - 15 billion tonnes $\mathrm{CO}_{2}$ in 2050 \\
\hline $\begin{array}{l}\text { DRI in Michaelis } \\
\text { (1996b) }\end{array}$ & $\begin{array}{l}\text { Removal of coal subsidies } \\
\text { in Europe and Japan }\end{array}$ & -10 to $-50 \mathrm{mtCO}_{2}$ \\
\hline \multirow[t]{2}{*}{$\begin{array}{l}\text { Van Beers et al. } \\
\text { (2002) } \\
\text { Netherlands }\end{array}$} & $\begin{array}{l}\text { Milk subsidy implicit in } \\
\text { price floors }\end{array}$ & $\begin{array}{l}59.6 \text { to } 229.2 \text { kilotonnes } \mathrm{CO}_{2} \\
55,900 \text { to } 215,000 \text { hectare of } \\
\text { additional land use for dairy } \\
\text { farming }\end{array}$ \\
\hline & $\begin{array}{l}\text { Designation of land for } \\
\text { agricultural use }\end{array}$ & $\begin{array}{l}1,958 \text { kilotonnes } \mathrm{CO}_{2} \\
217,800 \text { hectare of additional } \\
\text { land for agriculture }\end{array}$ \\
\hline $\begin{array}{l}\text { Saunders and } \\
\text { Schneider (2000) }\end{array}$ & $\begin{array}{l}\text { Removal of energy } \\
\text { consumption subsidies in } \\
\text { transitional and } \\
\text { developing economies } \\
\text { (effects in 2010) }\end{array}$ & $\begin{array}{l}1.1 \% \text { reduction in } \mathrm{CO}_{2} \text { (world) } \\
8 \% \text { reduction in } \mathrm{CO}_{2} \text { (transitional } \\
\text { economies) } \\
1 \% \text { increase in } \mathrm{CO}_{2} \text { (developed } \\
\text { countries) }\end{array}$ \\
\hline $\begin{array}{l}\text { Schmid at al. } \\
\text { (2007) } \\
\text { Austria }\end{array}$ & $\begin{array}{l}\text { Complete decoupling of } \\
\text { agricultural subsidies } \\
\text { from specific crops and } \\
\text { livestock }\end{array}$ & $\begin{array}{l}3.5 \% \text { reduction in methane } \\
1.1 \% \text { increase in soil carbon } \\
\text { sequestration } \\
3.1 \% \text { reduction in nitrate from } \\
\text { manure } \\
7.2 \% \text { reduction in nitrate from } \\
\text { fertilizers } \\
2.8 \% \text { reduction in nitrogen } \\
\text { surplus }\end{array}$ \\
\hline
\end{tabular}

Source: Based on Pearce (2003), with three studies added Notes: When removing a subsidy, pollution is generally reduced, and this is associated with a negative number in the table. Increases in pollution, noted with a positive number, are associated with the introduction or presence of a subsidy. 
Table 3: Economic Impacts of Proposed Changes in Vehicle Regulation

\begin{tabular}{|c|c|c|}
\hline Study & Approach & $\begin{array}{l}\text { Estimated } \\
\text { Impact }\end{array}$ \\
\hline \multicolumn{3}{|l|}{ CAFE } \\
\hline $\begin{array}{l}\text { Austin and Dinan } \\
(2005)\end{array}$ & $\begin{array}{l}\text { Cost saving from } \\
\text { implementing a } 10 \% \\
\text { reduction in gas consumption } \\
\text { via a tax versus increase in } \\
\text { CAFE }\end{array}$ & $\begin{array}{l}\text { Reduction in } \\
\text { cost of } 58-71 \% \\
\text { (depending on } \\
\text { discount rate) }\end{array}$ \\
\hline Kleit (2004) & $\begin{array}{l}\text { Cost savings from } \\
\text { implementing a } 3 \text { MPG } \\
\text { decrease in gasoline } \\
\text { consumption via tax versus } \\
\text { CAFÉ increase. } \\
\end{array}$ & $\begin{array}{l}\text { CAFE } 14 \text { times } \\
\text { more } \\
\text { expensive than } \\
\text { a comparable } \\
\text { gas tax }\end{array}$ \\
\hline \multirow[t]{2}{*}{$\begin{array}{l}\text { West and Williams } \\
\text { (2005) }\end{array}$} & $\begin{array}{l}\text { Marginal costs of gas tax in } \\
\text { second best }\end{array}$ & $\begin{array}{l}30 \% \text { lower } \\
\text { costs than in } \\
\text { first best }\end{array}$ \\
\hline & $\begin{array}{l}\text { Marginal costs of CAFÉ in } \\
\text { second best }\end{array}$ & $\begin{array}{l}60 \% \text { higher } \\
\text { than in first } \\
\text { best }\end{array}$ \\
\hline \multicolumn{3}{|c|}{ I mprovements to fuel taxes } \\
\hline \multirow[t]{2}{*}{$\begin{array}{l}\text { Parry and Small } \\
\text { (2005) }\end{array}$} & $\begin{array}{l}\text { Increasing current taxes to } \\
\text { optimal level in US }\end{array}$ & $\begin{array}{l}\text { Net benefits } \\
\text { equivalent to } \\
7.4 \% \text { of pre- } \\
\text { tax gas } \\
\text { expenditures }\end{array}$ \\
\hline & $\begin{array}{l}\text { Decreasing current taxes to } \\
\text { optimal level in UK }\end{array}$ & $\begin{array}{l}\text { Net benefits } \\
\text { equivalent to } \\
22.7 \% \text { of pre- } \\
\text { tax gas } \\
\text { expenditures }\end{array}$ \\
\hline \multicolumn{3}{|c|}{ Other regulation ( VMT, PAYD, congestion charges) } \\
\hline $\begin{array}{l}\text { Parry and Small } \\
(2005)\end{array}$ & $\begin{array}{l}\text { Replacing gas tax with VMT } \\
\text { tax in U.S. and UK }\end{array}$ & $\begin{array}{l}\text { Net benefits } \\
\text { equivalent to } \\
\text { about } 27 \% \text { of } \\
\text { pre-tax gas } \\
\text { expenditures }\end{array}$ \\
\hline Parry (2005) & $\begin{array}{l}\text { Achieving a } \sim 10 \% \text { reduction } \\
\text { in fuel use via gas tax }\end{array}$ & $\begin{array}{l}\text { Welfare gains } \\
\text { are only } 32 \% \\
\text { of doing the } \\
\text { same via PAYD }\end{array}$ \\
\hline Leape (2006) & London congestion charge & $\begin{array}{l}\text { Costs: GBP } 163 \\
\text { million } \\
\text { Benefits: GBP } \\
230 \text { million } \\
\end{array}$ \\
\hline
\end{tabular}


The University of Manchester

Sustainable

Consumption Institute

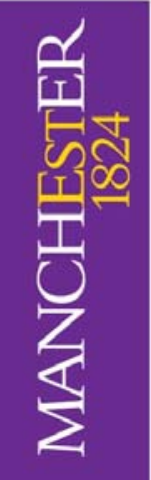

For more information about the Discussion Paper Series please contact:

Lynda Mcl ntosh, MCIPR

Communications and Marketing

Sustainable Consumption Institute

The University of Manchester

188 Waterloo Place

Oxford Road

Manchester, UK

M13 9PL

T: 01612750187

F: 01612750188

E: Lynda.mcintosh@manchester.ac.uk

Available online at www.sci.manchester.ac.uk/publications/DiscussionPaper/No2 